JURNAL ILMIAH KOMPUTERISASI AKUNTANSI, Vol. 14, No. 2, Desember 2021, pp.308 - 339

p-ISSN : 1979-116X (print)

e-ISSN : 2614-8870 (online)

http://journal.stekom.ac.id/index.php/kompak

- page 308

\title{
Penyajian Laporan Keuangan Entitas Berorientasi Non Laba Berdasarkan ISAK 35 Pada Gereja HKBP Km 55
}

Sahala Purba ${ }^{1}$, Andro Siregar ${ }^{2}$, Melva Esnida Saragih ${ }^{3}$, Purnama Sari Sinulingga ${ }^{4}$, Rasdianta Br Purba ${ }^{5}$, Vivi Valensya Br Karo ${ }^{6}$, Emiya Sri Hagana Br Brahmana ${ }^{7}$

${ }^{1}$ Universitas Methodist Indonesia

J1. Hangtuah No. 8 madras hulu,kec Medan Polonia No telp : (061) 4157882, e-mail: $\underline{\text { sahala824@ gmail.com }}$

${ }^{2}$ Universitas Methodist Indonesia

Jl. Hangtuah No. 8 madras hulu,kec Medan Polonia No telp : (061) 4157882, e-mail: androsiregar0705@ gmail.com,

${ }^{3}$ Universitas Methodist Indonesia

Jl. Hangtuah No. 8 madras hulu,kec Medan Polonia No telp : (061) 4157882, e-mail: melvaesnida@ gmail.com,

${ }^{4}$ Universitas Methodist Indonesia

Jl. Hangtuah No. 8 madras hulu,kec Medan Polonia No telp : (061) 4157882, e-mail: sari54762@gmail.com

${ }^{5}$ Universitas Methodist Indonesia

Jl. Hangtuah No. 8 madras hulu,kec Medan Polonia No telp : (061) 4157882, e-mail: , rasdiantapurba05@ gmail.com

${ }^{6}$ Universitas Methodist Indonesia

Jl. Hangtuah No. 8 madras hulu,kec Medan Polonia No telp : (061) 4157882, e-mail: vivivalensya131@ gmail.com,

${ }^{7}$ Universitas Methodist Indonesia

Jl. Hangtuah No. 8 madras hulu,kec Medan Polonia No telp : (061) 4157882, e-mail: emiyabrahmana00@ gmail.com

\begin{tabular}{ll}
\hline \multirow{2}{*}{ ARTICLE INFO } & ABSTRACT \\
\cline { 1 - 2 } Article history: & $\begin{array}{l}\text { This journal discusses the presentation of financial } \\
\text { statements on non-profit entities. Initially, non-profit } \\
\text { entities presented financial statements based on }\end{array}$ \\
$\begin{array}{l}\text { PSAK 45 which was later changed to ISAK 35. One } \\
\text { of the non-profit entities included in the church, the } \\
\text { Received in revised form 2 November 2021 }\end{array}$ & $\begin{array}{l}\text { most important aspect of which was financial } \\
\text { accountability. Good accountability is obtained from } \\
\text { Accepted 10 November 2021 } \\
\text { Available online 1 Desember 2021 }\end{array}$ \\
generally accepted accounting standards.
\end{tabular}

The purpose of this journal is to find out the presentation of financial statements based on the implementation of ISAK 35 which began on January 1,2020 . The object of this paper is the presentation of the financial statements of the HKBP KM 55 Church. The data were collected through a series of interviews and observations. The financial statements that will be produced are statements of financial position, statements of comprehensive income, statements of cash flows and notes to financial statements.

Keywords : ISAK 35, Non-Profit Entities, Financial Report 



\section{Pendahuluan}

Organisasi nirlaba atau organisasi nonprofit berbeda dengan organisasi bisnis dimana tujuan dari organisasi bisnis adalah mencapai laba sebesar-besar nya sedangkan untuk nirlaba adalah suatu organisasi yang bertujuan tidak komersial, tanpa ada perhatian terhadap hal-hal yang mencari laba. Standar akuntansi untuk penyusunan pelaporan keuangan pada entitas nirlaba telah diatur dan ditetapkan oleh IAI yaitu Pernyataan Standar Akuntansi Keuangan (PSAK) Nomor 45 tentang Pelaporan Keuangan Entitas Nirlaba. Laporan keuangan entitas nirlaba meliputi laporan posisi keuangan pada akhir periode, aktivitas dan arus kas untuk suatu periode pelaporan, dan CaLK.

Organisasi nirlaba pada umumnya memilih pemimpin, pengurus atau penanggungjawab yang menerima amanat dari para stakeholdernya. Terkait dengan konsep akuntabilitas dimana akuntansi sebagai sarana pertanggungjawaban akuntabilitas maka laporan keuangan perlu disajikan oleh organisasi nirlaba. Alasannya karena dengan laporan keuangan maka dapat menilai pertanggungjawaban dari pengurus/manajemen atas tugas, kewajiban dan kinerja yang diamanatkan kepadanya.

Organisasi nirlaba semenjak tahun 1997 diatur dengan Pernyataan Standar Akuntansi Keuangan (PSAK) 45. Namun mulai tahun 2019 PSAK 45 diganti dengan Interpretasi Standar Akuntansi Keuangan (ISAK) 35. Dengan keluarnya peraturan baru ini maka organisasi nirlaba menyusun laporan keuangannya sesuai dengan ISAK 35. Tapi munculnya peraturan baru ini, terasa sulit untuk diterapkan oleh organisasi nirlaba karena banyak organisasi nirlaba yang tidak memiliki latar belakang ilmu akuntansi sehingga sulit untuk melaksanakannya.

Entitas nirlaba merupakan entitas yang bergerak dalam bidang pelayanan masyarakat yang tidak bertujuan untuk mencari laba. Entitas nirlaba ini biasanya didirikan oleh masyarakat atau dikelola oleh swasta. Sumber dana yang didapat oleh entitas nirlaba biasanya berasal dari para donator atau penyumbang yang tidak mengharapkan imbal balik atas dana yang diberikan.

Di Indonesia terdapat 6 agama yang diakui oleh negara, salah satunya adalah agama Kristen yang tempat ibadahnya adalah gereja. Dimana gereja sebagai salah satu contoh organisasi nirlaba. Selain gereja digunakan untuk beribadah, gereja juga digunakan untuk belajar Pendalaman Alkitab (PA), tempat berkumpulnya umat kristiani dan tempat berbagi ilmu agama.

Penyajian laporan keuangan pada gereja seringkali dihadapkan pada dilema antara menjadi lebih profesional dan akuntabel sesuai standar, atau tetap bertahan dengan mengandalkan rasa saling percaya diantara sesama pengurus gereja. Lazimnya secara umum orang berkeinginan untuk menjadi lebih profesional dan tidak menghilangkan rasa saling percaya diantara sesama pengurus gereja yang sudah terjalin selama ini. Dibeberapa kasus yang terjadi adalah pengurus gereja yang tidak mau berubah karena dikhawatirkan akan merusak rasa saling percaya yang kuat selama ini.

Namun sangat disayangkan kita melihat fenomena yang terjadi saat ini bahwa ada gereja yang tidak dapat mengelola keuangannya dengan baik. Kebanyakan gereja hanya mencatat dan melaporkan kas masuk dan kas keluar saja. Gereja tidak melakukan pencatatan invetarisasi terhadap harta yang dimilikinya sehingga nilai ekonomis dari gereja tidak dapat diketahui. Hal ini yang mengunggah kami untuk melakukan kegiatan pengabdian membantu gereja dalam menyajikan laporan keuangannya. Karena kita ketahui bahwa menyusun laporan keuangan bukanlah suatu hal yang mudah apalagi yang sesuai dengan standar. Tim sudah pernah melakukan penyusunan laporan keuangan pada gereja dengan menggunakan standar lama yaitu PSAK 45 (sesuai CV). Dengan adanya pengalaman yang lalu serta adanya tuntutan pedoman yang baru ISAK 35 menjadikan hal ini sangat penting bagi kami untuk

Penyajian Laporan Keuangan Entitas Berorientasi Non Laba Berdasarkan ISAK 35 Pada Gereja HKBP Km 55 (Sahala Purba) 
melaksanakan kegiatan pengabdian pada gereja karena dapat mengembangkan ilmu untuk proses pembelajaran disamping membantu gereja secara khusus dan masyarakat pada umumnya. Harapannya dengan adanya laporan keuangan akan tercipta transparansi dan akuntabilitas dana gereja yang baik yang menjadi keinginan dari ruas.

\section{Metode Penelitian}

Teknik Pengumpulan data dapat diartikan sebagai langkah strategis dalam penelitian,data memainkan peran yang sangat penting, yang berfungsi sebagai titik awal. Dalam memproleh data yang dibutuhkan,penulis melakukan penelitian denan menggunakan metode pengumpulan data sebagai berikut :

a.Tinjauan Literatur

Dalam penelitian ini penulis melakukan pengumpulan data dengan cara membaca buku-buku yang tersedia diperpustakaan ataupun yang dimiliki oleh penulis yang sesuai dengan permasalahan yang akan dibahas oleh peneliti.

b. Wawancara

Pada penelitian ini penulis melakukan wawancara dengan pengurus gereja yaitu kepada pendeta dan yang paling penting adalah bendahara dan sekretaris dengan cara tanya jawab untuk mengumpulkan data .

c. Observasi

Peneliti melakukan pengamatan secara langsung ke entitas yang menjadi subjek penelitian penulis yaitu gereja HKBP Km 55 dan melakukan pengumpulan data yang langsung didapat dari lokasi penulis.

\section{Metode Analisis Data}

a. Primer

Metode ini dilakukan dengan analisis primer yang dilakukan dengan mendatangi langsung pihak entitas.

b. Sekunder

Mengunjungi langsung Gereja HKBP untuk melakukan peninjauan lapangan guna mendapatkan data yang dibutuhkan dalam penelitian.

3. Tinjauan Pustaka

\section{Pengertian Akuntansi}

Menurut Accounting Principle Board: “Akuntansi adalah suatu kegiatan jasa, fungsinyaa adalah memberikan informasi kuantitatif, umumnya dalam ukuran uang, mengenai suatu entitas ekonomi yang dimaksud untuk digunakan sebagai dasar membuat pilihan diantara beberapa alternatif dalam pengambilan keputusan ekonomi”

Menurut American Institute of Certified Public Accounting : "Akuntansi adalah seni,pencatatan, penggolongan dan pengikhtisaran dengan cara tertentu dalam ukuran uang, transaksi dan kejadian-

JURNAL ILMIAH KOMPUTERISASI AKUNTANSI Vol. 14, No. 2, Desember $2021: 308-339$ 
kejadian yang umumnya bersifat keuangan dan termasuk melaporkan hasil-hasilnya dari suatu entitas dalam rangka pengambilan keputusan ekonomi"

Charles T. Hongren dan Walter Harrison (2007:4) menyatakan bahwa akuntansi adalah system informasi yang mengukur aktivitas bisnis, memproses data menjadi laporan, dan mengkomunikasikan hasilnya kepada para pengambil keputusan.

Menurut Suwardjono (2005): akuntansi sebagai seperangkat pengertahuan yang mempelajari perekayasaan (teknologi) penyediaan jasa berupa informasi keuangan kuantitatif unit-unit organisasi dalam suatu lingkungan negara tertentu dan cara penyampaian (pelaporan) informasi tersebut kepada pihak yang berkepentingan untk dijadikan dasar dalam pengambilan keputusan.

Dari pengertian diatas kita melihat bahwa Akuntansi dilakukan oleh entitas ekonomi dan informasi yang dihasilkan adalah informssi mengenai entitas tersebut, dimana informasi yang dihasilkan tadi adalah berguna dalam pengambilan keputusan ekonomi baik oleh eksekutif yang diberi tugas memimpin entitas tersebut maupun pihak ekstern yang ingin mengetahui keberadaan entitas tersebut.

\section{Siklus Akuntansi}

Siklus akuntansi pada nonlaba umunya hamper sama dengan siklus akuntansi pada umumnya. Menurut Halim dan Kusufi (2013). Siklus akuntansi dikelompokkan dalam tiga tahap, yaitu:

a) Tahap pencatatan, terdiri dari kegiatan pengidentifikasian dan pengukuran dalam bentuk transaksi dan buku pencatatan, kegiatan pencatatan bukti transaksi ke dalam buku jurnal, dan memindah bukukan (posting) dari jurnal berdasarkan kelompok atau jenisnya ke dalam akun buku besar.

b) Tahap pengikhtisaran, terdiri dari penyusunan neraca saldo berdasarkan akun- akun buku besar, pembuatan ayat jurnal penyesuaian, penyusunan kertas keja, pembuatan ayat jurnal penutup, membuat neraca saldo setelah penutupan, membuat ayat jurnal pembalik.

c) Tahap pelaporan, yang terdiri dari Laporan posisi keuangan, laporan penghasilan komprehensif, laporan arus kas dan catatan atas laporam keuangan.

\section{ISAK 35 Penyajian LaPoran Keuangan entitas Berorientasi nonLaBa}

DE ISAK 35 menggunakan judul Penyajian Laporan Keuangan Entitas Berorientasi Nonlaba. DE ini mengatur penyajian laporan keuangan untuk entitas yang aktivitasnya berorientasi nonlaba. Penggunaan istilah "nonlaba" dalam DE ISAK 35 sejalan dengan istilah "nonlaba" ("not-for-profit") yang diusulkan dalam DE Amendemen PSAK 1: Penyajian Laporan Keuangan.

DE ISAK 35: Penyajian Laporan Keuangan Entitas Berorientasi Nonlaba paragraf 09-12 mengatur bagaimana entitas berorientasi nonlaba membuat penyesuaian ketika menyajikan laporan keuangannya. DE ISAK 35 paragraf 10 mengatur serta memberikan contoh penyesuaian deskripsi yang digunakan untuk beberapa pos yang terdapat dalam laporan keuangan. DE ISAK 35 paragraf 11 mengatur serta memberikan contoh penyesuaian deskripsi yang digunakan atas laporan keuangan itu sendiri. Jika entitas berorientasi nonlaba membuat penyesuaian atas judul

laporan keuangan, Interpretasi ini tidak membatasi penggunaan judul tertentu atas laporan keuangan sepanjang penggunaan judul mencerminkan fungsi yang lebih sesuai dengan isi laporan keuangannya.

Penyajian Laporan Keuangan Entitas Berorientasi Non Laba Berdasarkan ISAK 35 Pada Gereja HKBP Km 55 (Sahala Purba) 
DE ISAK 35: Penyajian Laporan Keuangan Entitas Berorientasi Nonlaba tidak mengatur mengenai ketentuan transisi. Hal ini mensyaratkan bahwa DE ISAK 35 menerapkan ketentuan umum dalam PSAK 25: Kebijakan Akuntansi, Perubahan Estimasi Akuntansi, dan Kesalahan terkait dengan perubahan kebijakan akuntansi. Jika terjadi perubahan kebijakan akuntansi akibat disyaratkan oleh SAK dan SAK tersebut tidak mengatur suatu ketentuan transisi, maka perubahan kebijakan akuntansi diterapkan secara retrospektif.

DE ISAK 35: Penyajian Laporan Keuangan Entitas Berorientasi Nonlaba diusulkan berlaku efektif untuk periode tahun buku yang dimulai pada atau setelah tanggal 1 Januari 2020. DE ISAK 35: Penyajian Laporan Keuangan Entitas Berorientasi Nonlaba tidak mengizinkan penerapan dini.

\section{Ruang Lingkup DE ISAK 35}

Penyajian Laporan Keuangan Entitas Berorientasi Nonlaba paragraf mengatur ruang lingkup penyajian laporan keuangan entitas berorientasi nonlaba terlepas dari bentuk badan hukum entitas tersebut. Interpretasi ini dapat diterapkan juga oleh entitas berorientasi nonlaba yang menggunakan Standar Akuntansi Keuangan Entitas Tanpa Akuntabilitas Publik (SAK ETAP).

\section{Interpretasi}

1. Penyajian laporan keuangan entitas berorientasi nonlaba disusun dengan memperhatikan persyaratan penyajian laporan keuangan, struktur laporan keuangan dan persyaratan minimal isi laporan keuangan yang telah diatur dalam PSAK 1: Penyajian Laporan Keuangan.

2. Entitas berorientasi nonlaba dapat membuat penyesuaian deskripsi yang digunakan untuk beberapa pos yang terdapat dalam laporan keuangan. Sebagai contoh, jika sumber daya yang diterima oleh entitas berorientasi nonlaba mengharuskan entitas untuk memenuhi kondisi yang melekat pada sumber daya tersebut, entitas dapat menyajikan jumlah sumber daya tersebut berdasarkan sifatnya, yaitu pada adanya pembatasan (with restrictions) atau tidak adanya pembatasan (without restrictions) oleh pemberi sumber daya.

3. Entitas berorientasi nonlaba juga dapat menyesuaikan deskripsi yang digunakan atas laporan keuangan itu sendiri. Sebagai contoh, penyesuaian atas penggunaan judul laporan perubahan aset neto daripada laporan perubahan ekuitas. Penyesuaian atas judul laporan keuangan tidak dibatasi sepanjang penggunaan judul mencerminkan fungsi yang lebih sesuai dengan isi laporan keuangannya.

4. Entitas berorientasi nonlaba tetap harus mempertimbangkan seluruh fakta dan keadaan relevan dalam menyajikan laporan keuangannya termasuk catatan atas laporan keuangan, sehingga tidak mengurangi kualitas informasi yang disajikan dalam laporan keuangan.

5. Presentation of Financial Statements paragraf 5 sebagai acuan PSAK 1: Penyajian Laporan Keuangan paragraf 05 mengizinkan entitas berorientasi nonlaba menyesuaikan deskripsi yang digunakan untuk beberapa pos yang terdapat dalam laporan keuangan dan laporan keuangan itu sendiri. PSAK 1 tidak memberikan penjelasan atau contoh lebih atas penyesuaian tersebut.

6. Interpretasi ini dilengkapi dengan contoh ilustratif yang bukan merupakan bagian dari DE ISAK 35 . Contoh ilustratif mencakup laporan posisi keuangan, laporan penghasilan komprehensif, laporan perubahan aset neto, laporan arus kas dan catatan atas laporan keuangan.

7. Contoh-contoh dalam Interpretasi ini tidak ditujukan untuk mengilustrasikan seluruh aspek dari SAK atau mencakup bentuk yang sesuai untuk seluruh entitas berorientasi nonlaba. Contoh ini dapat berbeda dari kondisi yang terdapat dalam entitas berorientasi nonlaba tertentu

JURNAL ILMIAH KOMPUTERISASI AKUNTANSI Vol. 14, No. 2, Desember $2021: 308-339$ 


\section{Tanggal Efektif}

Penyajian Laporan Keuangan Entitas Berorientasi Nonlaba diusulkan berlaku efektif untuk periode tahun buku yang dimulai pada atau setelah tanggal 1 Januari 2020.

\section{Ruang Lingkup dan Permasalahan ISAK 35}

a) Ruang lingkup ISAK 35: Penyajian Laporan Keuangan Entitas Berorientasi Nonlaba memberikan pedoman penyajian laporan keuangan untuk entitas berorientasi nonlaba sebagai Interpretasi dari PSAK 1: Penyajian Laporan Keuangan Paragraf 05.

b) Interpretasi ini diterapkan juga oleh entitas berorientasi nonlaba yang menggunakan Standar Akuntansi Keuangan Entitas Tanpa Akuntabilitas Publik (SAK ETAP).

c) Perundang-undangan di Indonesia yang mengatur secara spesifik mengenai definisi dan ruang lingkup entitas berorientasi nonlaba tidak ditemukan. Oleh karena itu, DSAK IAI tidak memberikan definisi atau kriteria untuk membedakan entitas berorientasi nonlaba dari entitas bisnis berorientasi laba.

d) Entitas melakukan penilaiannya sendiri untuk menentukan apakah entitas merupakan suatu entitas berorientasi nonlaba, terlepas dari bentuk badan hukum ISSN 2657-1080 ISSN 1858-3687 Akuntansi dan Manajemen Vol.15, No.2, 2020120 entitas tersebut, sehingga dapat menerapkan Interpretasi ini. .Beberapa faktor yang dapat dipertimbangkan entitas adalah:

(a) apakah sumber daya entitas berorientasi nonlaba berasal dari pemberi sumber daya yang tidak mengharapkan pembayaran kembali atau manfaat ekonomik yang sebanding dengan jumlah sumber daya yang diberikan;

(b) menghasilkan barang dan/atau jasa tanpa bertujuan memupuk laba, dan jika entitas berorientasi nonlaba menghasilkan laba, maka jumlahnya tidak dibagikan kepada pendiri atau pemilik entitas berorientasi nonlaba tersebut;

(c) tidak ada kepemilikan seperti umumnya pada entitas bisnis berorientasi laba, dalam arti bahwa kepemilikan dalam entitas berorientasi nonlaba tidak dapat dijual, dialihkan atau ditebus kembali atau kepemilikan tersebut tidak mencerminkan proporsi pembagian sumber daya entitas berorientasi nonlaba pada saat likuidasi atau pembubaran entitas berorientasi nonlaba.

\section{Laporan Keuangan Entitas Nonlaba Berdasarkan ISAK 35}

Pengertian laporan keuangan menurut Ikatan Akuntan Indonesia (2015) dalam Standar Akuntansi Keuangan (SAK) No. 1 dikemukakan bahwa Laporan keuangan merupakan bagian dari proses pelaporan keuangan dan laporan keuangan adalah suatu penyajian terstruktur dari posisi keuangan dan kinerja keuangan suatu entitas. Laporan keuangan yang lengkap biasanya meliputi neraca, laporan laba rugi, laporan perubahan posisi keuangan (yang dapat disajikan dalam berbagai cara misalnya, sebagai laporan arus kas, atau laporan arus dana), catatan dan laporan lain serta materi penjelasan yang merupakan bagian integral dari laporan keuangan. Tujuan laporan keuangan menurut Hans (2016 : 126) adalah memberikan informasi mengenai posisi keuangan, kinerja keuangan, dan arus kas entitas yang bermanfaat bagi sebagian besar pengguna laporan keuangan dalam membuat keputusan ekonomi. Laporan keuangan juga merupakan wujud pertanggung jawaban manajemen atas penggunaan sumber daya yang dipercayakan kepada mereka dalam mengelola suatu entitas.

Penyajian Laporan Keuangan Entitas Berorientasi Non Laba Berdasarkan ISAK 35 Pada Gereja HKBP Km 55 (Sahala Purba) 


\section{- $\quad$ p-ISSN : 1979-116X e-ISSN : 2614-8870}

Menurut ISAK 35 ada 5 jenis dan format laporan keuangan entitas nonlaba, yaitu: Laporan Posisi Keuangan, Laporan Penghasilan Komprehensif, Laporan Perubahan Aset Neto, Laporan Arus Kas, dan Catatan Atas Laporan Keuangan.

Berikut ini adalah format laporan keuangan entitas nonlaba versi ISAK 35 :

\section{Laporan Posisi Keuangan}

Laporan posisi keuangan entitas nonlaba terdiri dari 3 unsur, yaitu aset, liabilitas, dan aset neto. Terdapat 2 (dua) format Laporan Posisi Keuangan yang disajikan sebagai contoh dalam lampiran ISAK 35. Setiap format memiliki keunggulan masing-masing.

a) Aset

Menurut PSAK No. 16 Revisi Tahun 2011, aset adalah semua kekayaan yang dipunyai oleh individu ataupun kelompok yang berwujud maupun tidak berwujud, yang memiliki nilai akan memiliki manfaat bagi setiap orang atau perusahaan.

Pada umumnya entitas menyajikan dan mengumpulkan aset kelompok yang homogen. Diantaranya adalah:

a. Kas dan setara kas

b. Piutang pasien, pelajar, anggota, dan penerima jasa lain

c. Persediaan

d. Sewa, asuransi, dan jasa lain yang dibayar dimuka

e. Instrumen keuangan dan investasi jangka panjang

f. Tanah,gedung,peralatan, serta aset tetap lain yang digunakan untuk menghasilkan barang jasa

b) Liabilitas

Menurut IASC, Liabilitas adalah kewajiban masa kini dari perusahaan yang timbul dari peristiwa masa lalu, penyesuaian yang diharapkan dapat menghasilkan arus keluar dari sumber daya perusahaan dalam mewujudkan manfaat ekonomi. Liabilitas disusun berdasarkan urutan jatuh tempo dari liabilitas/ kewajiban tersebut. Kewajiban yang akan jatuh tempo kurang dari satu tahun digolongkan kewajiban lancer, sedangkan kewajiban yang akan jatuh tempo lenih dari satu tahun digolongkan kepada kewajiban jangka Panjang. Contoh urutan dan penyajian liabilitas/ kewajiban adalah:

Utang
a. Pendapatan diterima dimuka
b. Utang lainnya
c. Utang jangka Panjang

\section{Aset Neto}

Dalam laporan keuangan komersial, aset neto dikenal sebagai modal. Laporan posisi keuangan menyajikan jumlah masing-masing kelompok aset neto berdasarkan pada ada atau tidaknya pembatasan oleh pemberi sumber daya yang tidak mengharapkan pembayaran kembali. Aset neto neto berdasarkan kondisi yang melekat pada sumber daya menjadi dua klasifikasi aset neto yaitu:

a. Aset Neto Tanpa Pembatasan (without restrictions).

Aset neto tanpa pembatasan adalah aset neto yang tidak ada batasan terhadap aset tersebut, misalnya sumbangan yang diberikan oleh si donatur, dimana donatur tidak secara jelas mencantumkan jangka waktu dari donasinya tadi hanya untuk memberikan donasi untuk entitas tersebut sehingga pemasukan dan pengeluaran yang berhubungan dengan entitas dapat mempergunakannya untuk kebutuhan entitas.

JURNAL ILMIAH KOMPUTERISASI AKUNTANSI Vol. 14, No. 2, Desember 2021 : $308-339$ 
b. Aset Neto Dengan Pembatasan (with restrictions).

Aset neto dengan pembatasan, menggabungkan klasifikasi aset neto terikat permanen dan aset neto terikat temporer menjadi aset neto dengan pembatasan akan mengurangi kompleksitas. Aset neto dengan pembatasan adalah aset neto yang berkaitan dengan sumber daya berupa aktivitas operasi tertentu, investasi untuk jangka waktu tertentu, dan aset neto yang digunakan untuk selamanya, seperti tanah dan bangunan yang diberikan untuk tujuan tertentu, sehingga pemasukan dan pengeluarannya itu diluar entitas seperti kas anak yatim, kas fakir miskin dan lain lain.

Terdapat 2 (dua) format Laporan Posisi Keuangan yang disajikan :

1. Format A menyajikan informasi pos penghasilan komprehensif lain secara tersendiri sebagai bagian dari aset neto tanpa pembatasan dari pemberi sumber daya. Akan tetapi, jika penghasilan komprehensif lain berasal dari aset neto dengan pembatasan, maka entitas menyajikan informasi penghasilan komprehensif lain tersebut sesuai dengan kelas aset netonya

2. Format B tidak menyajikan informasi pos penghasilan komprehensif lain secara tersendiri.

\begin{tabular}{|c|c|c|}
\hline \multicolumn{3}{|c|}{$\begin{array}{c}\text { ENTITAS XYZ } \\
\text { Laporan Posial Keuangan per } 31 \text { Desember } 20 \times 2 \\
\text { (dalan jutaan ruplah) }\end{array}$} \\
\hline & $20 \times 2$ & $20 \times 1$ \\
\hline \multicolumn{3}{|l|}{ ASET } \\
\hline \multicolumn{3}{|l|}{ Aset Lancar } \\
\hline Kas dan setara kas & $\operatorname{xxxx}$ & $\operatorname{xxxx}$ \\
\hline Piutang bunga & $\operatorname{xxxx}$ & $\operatorname{xxxx}$ \\
\hline Investasi jangka pendek & $\operatorname{xxxx}$ & $\operatorname{xxxx}$ \\
\hline Aset lancar lain & $\operatorname{xxxx}$ & $\operatorname{xxxx}$ \\
\hline Total Aset Lancar & $\operatorname{xxxx}$ & $x \times x x$ \\
\hline \multicolumn{3}{|l|}{ Aset Tidak Lancar } \\
\hline Properti investasi & $\operatorname{xxxx}$ & $\operatorname{xxxx}$ \\
\hline Investasi jangka panjang & $\operatorname{xxxx}$ & $\operatorname{xxxx}$ \\
\hline Aset tetap & $\operatorname{xxxx}$ & $\operatorname{xxxx}$ \\
\hline Total Aset Tidak Lancar & $\operatorname{xxxx}$ & $\operatorname{xxxx}$ \\
\hline TOTAL ASET & $\operatorname{xxcxx}$ & $\operatorname{xxxx}$ \\
\hline \multicolumn{3}{|l|}{ LIABILITAS } \\
\hline \multicolumn{3}{|l|}{ Liabilitas Jangka Pendek } \\
\hline Pendapatan diterima di muka & $\operatorname{xxxx}$ & $\operatorname{xxxx}$ \\
\hline Utang jangka pendek & $\operatorname{xxxx}$ & $\operatorname{xxxx}$ \\
\hline Total Ltabilitas Jangka Pendek & $\operatorname{xxxx}$ & $\operatorname{xxxx}$ \\
\hline Liabititas Jangka Panjang & & \\
\hline Utang jangka panjang & $x x x x$ & $\operatorname{xxxx}$ \\
\hline Liabilitas imbalan kerja & $\operatorname{xxxx}$ & $\operatorname{xxxx}$ \\
\hline Total Liabilitas Jangka Panjang & $\operatorname{xxxx}$ & $\operatorname{xxxx}$ \\
\hline Total Liabilitas & $\operatorname{xxcxx}$ & $\operatorname{xxxx}$ \\
\hline
\end{tabular}

Penyajian Laporan Keuangan Entitas Berorientasi Non Laba Berdasarkan ISAK 35 Pada Gereja HKBP Km 55 (Sahala Purba) 
ASET NETO

Tanpa pembatasan (without restrictions) dari

pemberi sumber daya

Surplus akumulasian

Penghasilan komprehensif lain ${ }^{*}$ )

Dengan pembatasan (with restrictions) dari

pemberi sumber daya (catatan $B$ )

Total Aset Neto

TOTAL LIABILITAS DAN ASET NETO

Contoh Laporan Posisi Keuangan (Format A)

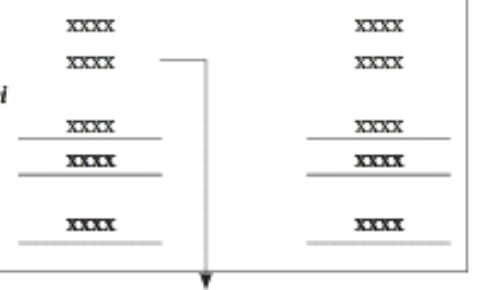

(A)

Gambar 1. Bentuk Laporan Posisi Keuangan A

Sumber: SAK IAI ONLINE (ISAK 35)

Contoh Laporan Posisi Keuangan (Format B)

\begin{tabular}{|c|c|c|}
\hline \multicolumn{3}{|c|}{$\begin{array}{c}\text { ENTITAS XYZ } \\
\text { Laporan Posisi Keuangan per } 31 \text { Desember } 20 X 2 \\
\text { (dalam fetaan ruplah) }\end{array}$} \\
\hline & $20 \times 2$ & $20 \times 1$ \\
\hline \multicolumn{3}{|l|}{ ASET } \\
\hline \multicolumn{3}{|l|}{ Aset Lancar } \\
\hline Kas dan setara kas & $x x x x$ & $x x x x$ \\
\hline Piutang bunga & $x x x x$ & $x x x x$ \\
\hline Investasi jangka pendek & $x x x x$ & $\operatorname{xxxx}$ \\
\hline Aset lancar lain & $x \times x$ & $\operatorname{xxxx}$ \\
\hline Total Aset Lancar & $x x 0 x$ & $\operatorname{xxxx}$ \\
\hline \multicolumn{3}{|l|}{ Aset Tidak Lancar } \\
\hline Properti investasi & $\operatorname{xxcx}$ & $x x x x$ \\
\hline Investasi jangka panjang & $x x x x$ & $\operatorname{xxxx}$ \\
\hline Aset tetap & $x x x x$ & $x \times x x$ \\
\hline Total Aset Tidak Lancar & $x \times x x$ & $\operatorname{xxxx}$ \\
\hline TOTAL ASET & xox & $x \times x x$ \\
\hline \multicolumn{3}{|l|}{ LIABILITAS } \\
\hline \multicolumn{3}{|l|}{ Labilitas Jangka Pendek } \\
\hline Pendapatan diterima di muka & $\operatorname{xxcx}$ & $x x x x$ \\
\hline Utang jangka pendek & $\operatorname{xxxx}$ & $\operatorname{xxxx}$ \\
\hline Total Liabilitas Jangka Pendek & $x 00 x$ & $\operatorname{xxxx}$ \\
\hline \multicolumn{3}{|l|}{ Labilitas Jangka Panjang } \\
\hline Utang jangka panjang & $x+0 x$ & $\operatorname{xxxx}$ \\
\hline Liabilitas imbalan kerja & $x+0 x$ & $\operatorname{xxxx}$ \\
\hline Total Liabilitas Jangka Panjang & $x 000 x$ & $x x x x$ \\
\hline Total Liabilitas & $x+x$ & $x \times x x$ \\
\hline
\end{tabular}

JURNAL ILMIAH KOMPUTERISASI AKUNTANSI Vol. 14, No. 2, Desember 2021 : $308-339$ 


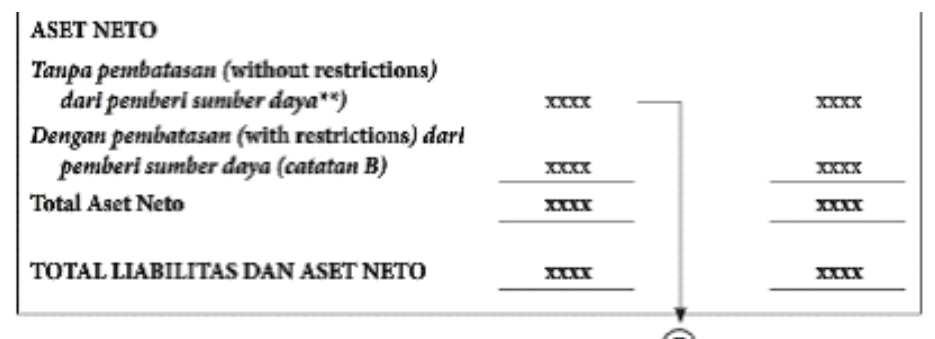

Gambar 2. Bentuk Laporan Posisi Keuangan B

Sumber: SAK IAI ONLINE (ISAK 35)

\section{Laporan Penghasilan Komprehensif}

Laporan yang menyajikan laporan laba rugi untuk suatu periode yang merupakan kinerja keuangan selama periode tersebut. Dimana laporan ini juga mengatur informasi yang disajikan dalam laporan laba rugi seperti penghasilan dan beban entitas untuk suatu periode

Informasi yang disajikan dalam laporan laba rugi:

a) Pendapatan

b) Beban keuangan

c) Bagian laba atau rugi dari investasi yang menggunakan metode ekuitas

d) Beban pajak

e) Laba rugi atau rugi neto

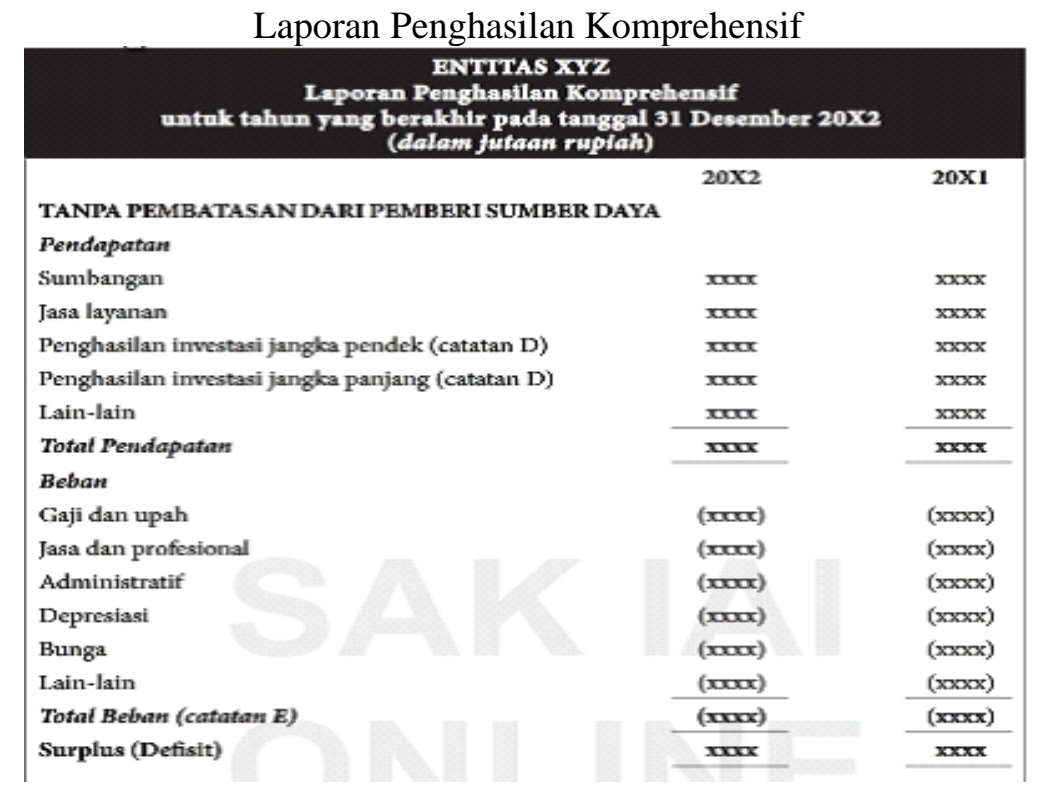




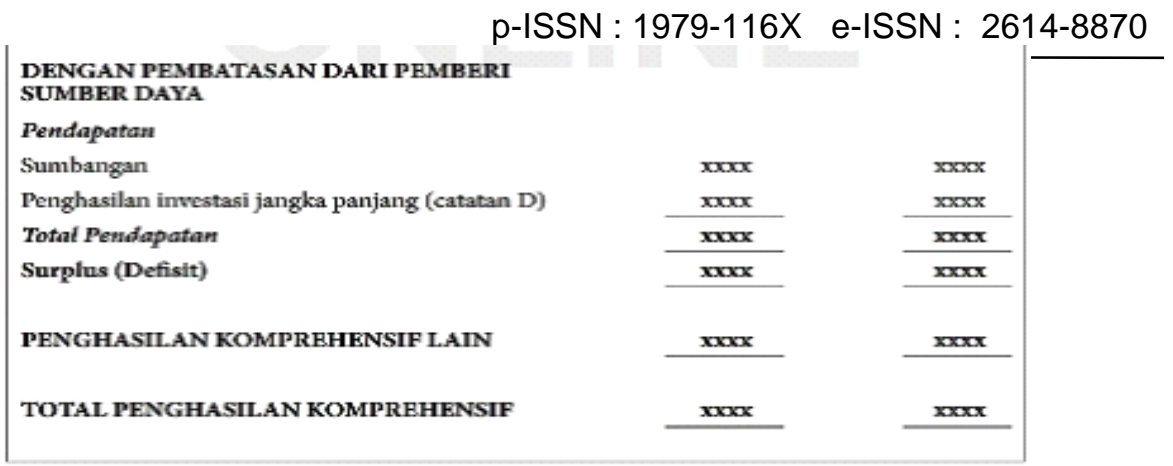

Gambar 3. Bentuk Laporan Komperensif

Sumber :SAK IAI ONLINE (ISAK 35)

\section{Laporan perubahan Aset Neto}

Dalam penyusunan laporan keuangan berdasarkan interprestasi standar akuntansi keuangan (ISAK 35) merupakan laporan perubahan aset neto menyajikan informasi aset neto tanpa pembatasan dari pemberi sumber daya dan aset neto dengan pembatasan dari pemberi sumber daya. Berikut contoh laporan perubahan aset neto:

Contoh Laporan Perubahan Aset Neto

\begin{tabular}{|c|c|c|}
\hline \multicolumn{3}{|c|}{$\begin{array}{c}\text { ENTITAS XYZ } \\
\text { Laporan Perubahan Aset Neto } \\
\text { untuk tahun yang beralkitr pada tanggal } 31 \text { Desember } 20 \mathrm{X} 2 \\
\text { (dalam jutaan rupiah) }\end{array}$} \\
\hline & $20 \times 2$ & 20XI \\
\hline \multicolumn{3}{|l|}{$\begin{array}{l}\text { ASET NETO TANPA PEMBATASAN DARI } \\
\text { PEMBERI SUMBER DAYA }\end{array}$} \\
\hline Saldo awal & $x x x x$ & $x x x$ \\
\hline Surplus tahun berjalan & $x x x x$ & $x x x$ \\
\hline $\begin{array}{l}\text { Aset neto yang dibebaskan dari pembatasan } \\
\text { (catatan C) }\end{array}$ & $\operatorname{xxxx}$ & $x x x$ \\
\hline Saldo akhir & $x \mathbf{x x}$ & $\operatorname{xrxx}$ \\
\hline \multicolumn{3}{|l|}{ Penghasilan Komprehensif Lain } \\
\hline Saldo awal & $x x x$ & $x x x$ \\
\hline Peghasilan komprehensif tahun berjalan***) & $x x x$ & $x \mathrm{xx}$ \\
\hline Saldo akhir & $x x x$ & $\operatorname{xxx}$ \\
\hline 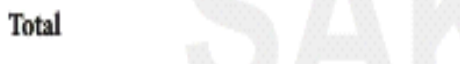 & $x \times x$ & $\operatorname{xxx}$ \\
\hline
\end{tabular}

JURNAL ILMIAH KOMPUTERISASI AKUNTANSI Vol. 14, No. 2, Desember 2021 : $308-339$ 


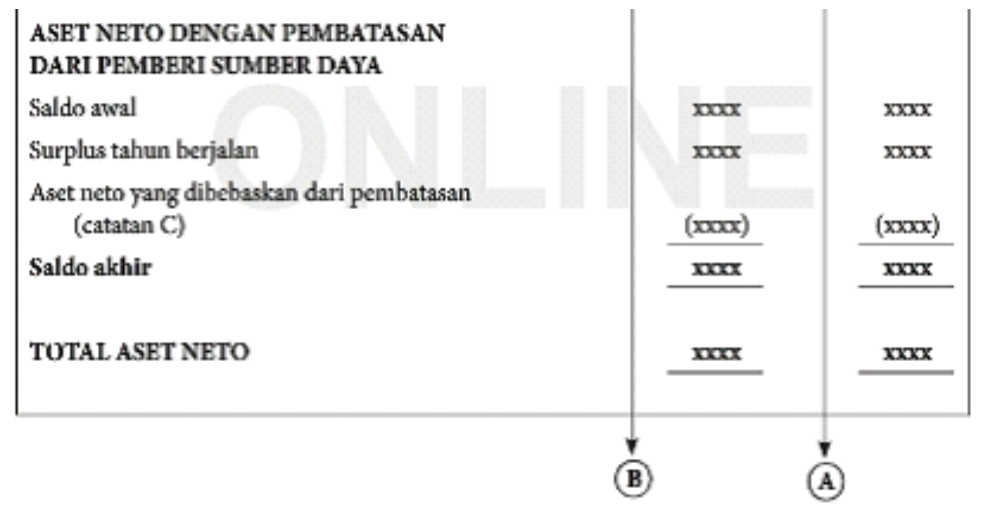

Gambar 4. Bentuk Laporan Perubahan Aset Neto

\section{4) Laporan Arus Kas}

Sumber: SAK IAI ONLINE (ISAK 35)

Laporan arus kas adalah laporan yang menunjukkan penerimaan dan pengeluaran kas dan setara kas selama periode tertentu yang dikelompokan dalam aktivitas operasional, aktivitas investasi dan aktivitas pendanaan. Informasi tentang arus kas berguna bagi para pengguna laporan keuangan sebagai dasar untuk menilai kemampuan masjid dalam menghasilkan kas dan setara kas serta menilai kebutuhanpengguna arus kas tersebut. Laporan arus kas disajikan sesuai dengan dasar pengaturan SAK ETAP Bab 7 dengan tambahan berikut ini:

1. Aktivitas Operasi

Aktivitas penghasil utama pendapatan dan aktivitas lain yang bukan merupakan aktivitas investasi dan aktivitas pendanaan.

2. Aktivitas Investasi

Aktivitas perolehan dan pelepasan aset jangka panjang serta investasi lain yang tidak termasuk setara kas.

3. Aktivitas Pendanaan

Penerimaan kas dari pemberi sumber daya yang tidak mengharapkan pembayaran kembali yang penggunaannya dibatasi dalam jangka panjang, Penerimaan kas dari pemberi sumber daya dan penghasilan investasi yang penggunaannya dibatasi untuk pembangunan dan pemeliharaan aset tetap, atau peningkatan dana abadi dan imbal hasil dan dividen yang dibatasi penggunanya dalam jangka panjang.

Adapun bentuk Laporan Arus Kas yang disajikan dengan metode tidak langsung

menurut ISAK No. 35 adalah sebagai berikut: 
Contoh Laporan Arus Kas (Metode Tidak Langsung)

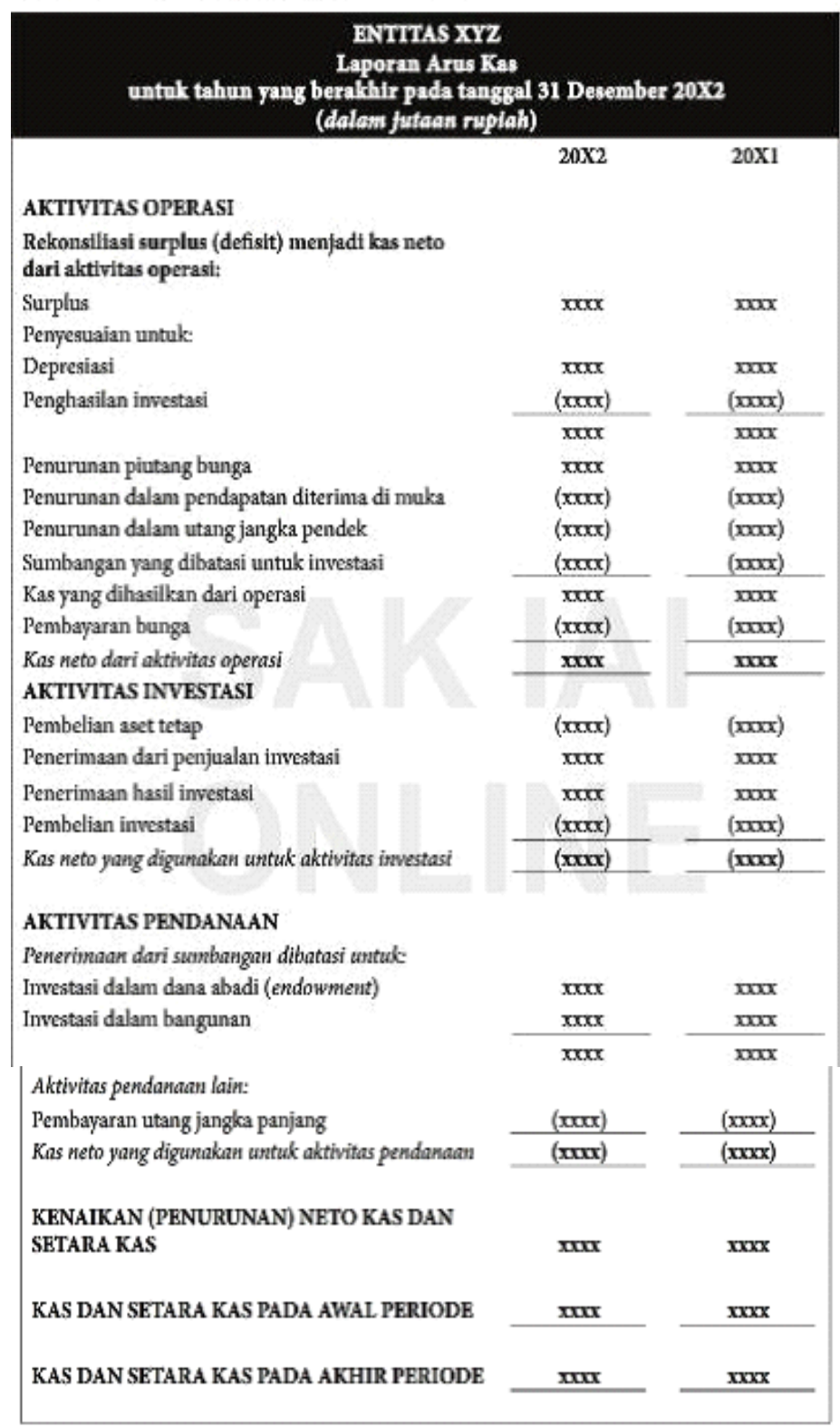

Gambar 5. Bentuk Laporan Arus Kas

Sumber : SAK IAI ONLINE (ISAK 35)

\section{5) Catatan Atas Laporan Keuangan}

Catatan atas laporan keuangan merupakan bagian yang tidak terpisah dari laporan-laporan di atas. Bertujuan memberikan informasi tambahan tentang perkiraanperkiraan yang diyatakan dalam laporan keuangan. Catatan atas laporan keuangan ini berupa perincian dari suatu perkiraaan yang disajikan seperti

JURNAL ILMIAH KOMPUTERISASI AKUNTANSI Vol. 14, No. 2, Desember 2021 : $308-339$ 
misalnya aset tetap. Catatan atas laporan keuangan memberikan rincian nama aset, liabilitas, aset neto. Misalnya, untuk aset tetap di catatan atas laporan keuangan akan dijelaskan untuk menghitung penyusutan aset tetap, serta kebijakan akuntansi lainnya yang digunakan oleh entitas tersebut.

\section{HASIL DAN PEMBAHASAN}

Berdasarkan hasil dari penelitian, terdapat beberapa data yang dapat dikumpulkan, sehingga menghasilkan laporan keuangan sebagai berikut :

a. Laporan Penghasilan Komprehensif

Pada laporan penghasilan dapat dilihat pada kolom perubahan asset neto terdapat penambahan (pengurangan) masing-masing asset neto pada akhir periode. Namun pada bulan januari 2020 aset neto gereja secara keseluruhan mengalami penurunan dapat dilihat pada kolom total penghasilan komprehensif. Pada awal januari 2020 total asset neto adalah Rp.12.317.020.000 Sedangkan akhir januari 2020 total asset neto mengalami penurunan menjadi Rp.12.314.013.500

\begin{tabular}{|c|c|c|c|}
\hline \multicolumn{4}{|c|}{$\begin{array}{l}\text { GEREJA HKBP KM } 55 \\
\text { LAPORAN PENGHASILAN KOMPREHENSIF } \\
\text { UNTUK PERIODE YANG BERKAHIR BULAN JANUARI } 2020\end{array}$} \\
\hline $\begin{array}{l}\text { Tanpa Pembatasan dari pemberi Sumber } \\
\text { daya }\end{array}$ & & $\mathbf{T P}$ & \\
\hline Pendapatan tanpa pembatasan & & $\mathbf{T P}$ & \\
\hline Kolekte minggu & $2 \mathrm{~g}, 9$ & TP & $10,500,000$ \\
\hline Pendapatan ibadah sekolah minggu & $2 \mathrm{~g}, 9$ & $\mathrm{TP}$ & $2,310,000$ \\
\hline Pendapatan ibadah muda mudi & $2 \mathrm{~g}, 9$ & $\mathrm{TP}$ & $2,400,000$ \\
\hline Pendapatan ibadah parinangan & $2 \mathrm{~g}, 9$ & TP & $2,150,000$ \\
\hline Pendapatan ibadah parbapaon & $2 \mathrm{~g}, 9$ & $\mathrm{TP}$ & $2,700,000$ \\
\hline Pendapatan hasil sewa wisma gereja & $2 g, 9$ & $\mathrm{TP}$ & $2,000,000$ \\
\hline Total pendapatan tanpa pembatasan & & & $22,060,000$ \\
\hline Beban - beban & & - & - \\
\hline Beban tanpa pembatasan & & TP & - \\
\hline Beban honor petugas gereja & $2 g, 11$ & TP & $2,710,000$ \\
\hline Beban honor Pendeta & $2 \mathrm{~g}, 11$ & $\mathrm{TP}$ & $3,900,000$ \\
\hline Beban administrasi kas bank gereja & $2 \mathrm{~g}, 11$ & $\mathrm{TP}$ & 6,500 \\
\hline Beban listrik & $2 \mathrm{~g}, 11$ & $\mathrm{TP}$ & $2,100,000$ \\
\hline Beban fotocopy & $2 \mathrm{~g}, 11$ & $\mathrm{TP}$ & 120,000 \\
\hline Beban air & $2 g, 11$ & $\mathrm{TP}$ & 40,000 \\
\hline Beban laundry & $2 \mathrm{~g}, 11$ & $\mathrm{TP}$ & 30,000 \\
\hline Beban transportasi pendeta & $2 g, 11$ & $\mathrm{TP}$ & $2,500,000$ \\
\hline Beban petugas kebersihan gereja & $2 \mathrm{~g}, 11$ & $\mathrm{TP}$ & 750,000 \\
\hline Total beban tanpa pembatasan & & & $12,156,500$ \\
\hline Surplus (defisit) tanpa pembatasan & & & 9,903,500 \\
\hline
\end{tabular}




\begin{tabular}{|l|l|l|l|}
\hline \multicolumn{2}{|l|}{ p-ISSN : 1979-116X e-ISSN : 2614-8870 } \\
\hline $\begin{array}{l}\text { Dengan pembatasan dari pemberi sumber } \\
\text { daya }\end{array}$ & & & \\
\hline Pendapatan dengan pembatasan & & DP & - \\
\hline Pendapatan sumbangan anak yatim & $2 \mathrm{~g}, 10$ & $\mathrm{DP}$ & $7,200,000$ \\
\hline Pendapatan sumbangan panti jompo & $2 \mathrm{~g}, 10$ & $\mathrm{DP}$ & $4,300,000$ \\
\hline Pendapatan bagi hasil fakir miskin & $2 \mathrm{~g}, 10$ & $\mathrm{DP}$ & $9,200,000$ \\
\hline Pendapatan bagi hasil anak yatim & $2 \mathrm{~g}, 10$ & $\mathrm{DP}$ & $9,600,000$ \\
\hline Pendapatan sumbangan pemuda gereja & $2 \mathrm{~g}, 10$ & $\mathrm{DP}$ & $5,660,000$ \\
\hline Total pendapatan dengan pembatasan & & & $\mathbf{3 5 , 9 6 0 , 0 0 0}$ \\
\hline Total pendapatan & & & $\mathbf{5 8 , 0 2 0 , 0 0 0}$ \\
\hline Beban dengan pembatasan & & DP & \\
\hline Beban anak yatim & $2 \mathrm{~g}, 12$ & $\mathrm{DP}$ & $5,850,000$ \\
\hline Beban panti jompo & $2 \mathrm{~g}, 12$ & $\mathrm{DP}$ & $5,980,000$ \\
\hline Beban fakir miskin & $2 \mathrm{~g}, 12$ & $\mathrm{DP}$ & $8,000,000$ \\
\hline Beban pemuda gereja & $2 \mathrm{~g}, 12$ & $\mathrm{DP}$ & $4,000,000$ \\
\hline Beban penyusutan peralatan gereja & $2 \mathrm{~g}, 12$ & $\mathrm{DP}$ & $5,900,000$ \\
\hline Beban perlengkapan gereja & $2 \mathrm{~g}, 12$ & $\mathrm{DP}$ & $10,990,000$ \\
\hline Beban penyusutan bangunan gereja & $2 \mathrm{~g}, 12$ & $\mathrm{DP}$ & $4,250,000$ \\
\hline Beban penyusutan bangunan tk/paud HKBP & $2 \mathrm{~g}, 12$ & $\mathrm{DP}$ & $3,900,000$ \\
\hline Total beban dengan pembatasan & & & $\mathbf{4 8 , 8 7 0 , 0 0 0}$ \\
\hline Total beban & & & $\mathbf{6 1 , 0 2 6 , 5 0 0}$ \\
\hline Surplus (defisit) dengan pembatasan & & & $\mathbf{- 1 2 , 9 1 0 , 0 0 0}$ \\
\hline Penghasilan komprehensif lain & & & - \\
\hline Total Penghasilan komprehensif & & & $\mathbf{- 3 , 0 0 6 , 5 0 0}$ \\
\hline
\end{tabular}

Gambar 6. Laporan Penghasilan Komprehensif

Sumber : Gereja

b. Laporan perubahan asset neto

Laporan perubahan asset neto merupakan laporan yang memberikan informasi mengenai perubahan asset neto yang terjadi di suatu entitas non laba. Didalam laporan perubahan asset neto terdapat dua kelompok asset neto yaitu, asset neto tanpa pembatasan asset neto dengan pembahasan. Pada laporan ini dapat diperoleh informasi mengenai surplus atau defisit asset neto dalam periode. Berikut laporan perubahan asset neto Gereja bulan januari 2020 :

\begin{tabular}{|c|c|}
\hline $\begin{array}{l}\text { GEREJA HKBP KM } 55 \\
\text { LAPORAN PERUBAHAN ASET NETO } \\
\text { UNTUK PERIODE YANG BERAKHIR B }\end{array}$ & LAN JANUARI 2020 \\
\hline $\begin{array}{l}\text { Aset neto tanpa pembatasan dari pemberi } \\
\text { sumber daya }\end{array}$ & \\
\hline Saldo awal & $41,200,000$ \\
\hline Surplus tahun berjalan & $9,903,500$ \\
\hline
\end{tabular}

JURNAL ILMIAH KOMPUTERISASI AKUNTANSI Vol. 14, No. 2, Desember $2021: 308-339$ 
JURNAL ILMIAH KOMPUTERISASI AKUNTANSI p-ISSN : 1979-116X e-ISSN : 2614-8870 •

\begin{tabular}{|l|l|} 
Saldo akhir & $\mathbf{5 1 , 1 0 3 , 5 0 0}$ \\
\hline $\begin{array}{l}\text { Aset neto dengan pembatasan dari } \\
\text { pemberi sumber daya }\end{array}$ & \\
\hline Saldo awal & $12,250,000,000$ \\
\hline Surplus (defisit) tahun berjalan & $-12,910,000$ \\
\hline Saldo akhir & $\mathbf{1 2 , 2 6 2 , 9 1 0 , 0 0 0}$ \\
\hline & \\
\hline TOTAL ASET NETO & $\mathbf{1 2 , 3 1 4 , 0 1 3 , 5 0 0}$ \\
\hline
\end{tabular}

Gambar 7. Laporan Perubahan Aset Neto

Sumber : Gereja

c. Laporan Posisi Keuangan

Laporan Posisi Keuangan gereja, menggambarkan asset(harta),liabilitas(utang) dan asset neto (modal) gereja. Dalam laporan posisi keuangan kita dapat melihat saldo akhir dari kas gereja, totl nilai asset asset dari gereja , dan juga dapat melihat liabilitas yang harus dipenuhi gereja. Untuk saldo akhir asset neto, nilainya diambil dari laporan penghasilan komprehensif yang mana telah mengalami kenaikan atau penurunan.

Berikut laporan posisi keuangan gereja dibulan januari 2020 :

\begin{tabular}{|c|c|}
\hline \multicolumn{2}{|l|}{$\begin{array}{l}\text { GEREJA HKBP KM } 55 \\
\text { LAPORAN POSISI KEUANGAN } \\
\text { PER } 31 \text { JANUARI } 2021\end{array}$} \\
\hline ASET & \\
\hline \multicolumn{2}{|l|}{ ASET LANCAR } \\
\hline Kas dan setara kas & $1,200,000,000$ \\
\hline Perlengkapan gereja & $24,700,000$ \\
\hline Perlengkapan pendidikan/tk/paud HKBP & $1,200,000$ \\
\hline TOTAL ASET LANCAR & $1,225,900,000$ \\
\hline \multicolumn{2}{|l|}{ ASET TIDAK LANCAR } \\
\hline Tanah & $8,157,013,500$ \\
\hline Bangunan gereja & $1,200,000,000$ \\
\hline Akm. Penyusutan bangunan gereja & $-890,900,000$ \\
\hline
\end{tabular}

Penyajian Laporan Keuangan Entitas Berorientasi Non Laba Berdasarkan ISAK 35 Pada Gereja HKBP Km 55 (Sahala Purba) 


\begin{tabular}{|l|l|}
\hline \multicolumn{2}{|c|}{ p-ISSN : 1979-116X e-ISSN : 2614-8870 } \\
\hline Bangunan tk/paud HKBP & $800,000,000$ \\
\hline Akm.penyusutan bangunan tk/paud HKBP & $-450,000,000$ \\
\hline Peralatan gereja & $250,000,000$ \\
\hline Akm. Penyusutan peralatan gereja & $-78,000,000$ \\
\hline Peralatan tk/paud HKBP & $4,300,000,000$ \\
\hline Akm. Penyusutan peralatan tk/paud HKBP & $-2,200,000,000$ \\
\hline TOTAL ASET TIDAK LANCAR & $\mathbf{1 1 , 0 8 8 , 1 1 3 , 5 0 0}$ \\
\hline TOTAL ASET & $\mathbf{1 2 , 3 1 4 , 0 1 3 , 5 0 0}$ \\
\hline Liabilitas & 0 \\
\hline Utang entitas & 0 \\
\hline Titipan & 0 \\
\hline TOTAL LIABILITAS & \\
\hline Aset neto & 0 \\
\hline Aset neto tanpa pembatasan & \\
\hline Aset neto dengan pembatasan & $\mathbf{1 2 , 3 1 4 , 0 1 3 , 5 0 0}$ \\
\hline TOTAL ASET NETO & $\mathbf{1 2 , 3 1 4 , 0 1 3 , 5 0 0}$ \\
\hline TOTAL LIABILITAS DAN ASET NETO & $12,262,910,000$ \\
\hline
\end{tabular}

Gambar 8. Laporan Posisi Keuangan Sumber : Gereja

d. Laporan Arus Kas

Tujuan dibuatnya laporan arus kas adalah untuk melihat saldo kas akhir suatu entitas, dan melihat arus kas (cash flow) pemasukan dan pengeluaran. Laporan arus kas hanya menunjukan kas masuk dank as keluar saja, jika tidak sama dengan saldo kas yang ada dalam laporan posisi keuangan, kemungkinan terjadi salah catat.

Berikut laporan arus kas gereja bulan januari 2020:

JURNAL ILMIAH KOMPUTERISASI AKUNTANSI Vol. 14, No. 2, Desember 2021 : $308-339$ 
JURNAL ILMIAH KOMPUTERISASI AKUNTANSI p-ISSN : 1979-116X e-ISSN : 2614-8870 •

\section{GEREJA HKBP KM 55 \\ LAPORAN ARUS KAS}

UNTUK PERIODE YANG BERAKHIR BULAN JANUARI 2020

(Disajikan dalam Rupiah)

\begin{tabular}{|l|l|}
\hline AKTIVITAS OPERASI & \\
\hline $\begin{array}{l}\text { Rekonsiliasi surplus (defisit) menjadi kas neto dari aktivitas } \\
\text { operasi: }\end{array}$ & \\
\hline Perubahan dalam aset neto & $-3,006,500$ \\
\hline $\begin{array}{l}\text { Penyesuaian untuk rekonsiliasi dalam aset neto menjadi kas } \\
\text { neto yang digunakan untuk aktivitas operasi: }\end{array}$ & \\
\hline Ditambah: & \\
\hline Beban penyusutan peralatan gereja & $5,900,000$ \\
\hline Beban penyusutan peralatan tk/paud HKBP & $5,980,000$ \\
\hline Beban penyusutan bangunan gereja & $4,250,000$ \\
\hline Beban penyusutan bangunan tk/paud HKBP & $3,900,000$ \\
\hline Penurunan perlengkapan gereja & 200,000 \\
\hline Penurunan perlengkapan tk/paud HKBP & 150,000 \\
\hline Kas neto yang diterima dari kegiatan operasi : & $\mathbf{1 7 , 3 7 3 , 5 0 0}$ \\
\hline & \\
\hline KKTIVITAS INVESTASI & - \\
\hline & $\mathbf{-}$ \\
\hline KENAIKAN (PENURUNAN) ASET NETO DALAM & $\mathbf{1 7 , 3 7 3 , 5 0 0}$ \\
\hline & - \\
\hline Kas neto yang diterima dari kegiatan pendanaan: & - \\
\hline & \\
\hline & \\
\hline
\end{tabular}

Penyajian Laporan Keuangan Entitas Berorientasi Non Laba Berdasarkan ISAK 35 Pada Gereja HKBP 


\begin{tabular}{|l|l|}
\hline KAS DAN SETARA KAS & p-ISSN : 1979-116X e-ISSN : 2614-8870 \\
\hline KAS DAN SETARA KAS PADA AWAL BULAN & $\mathbf{1 , 1 8 2 , 6 2 6 , 5 0 0}$ \\
\hline KAS DAN SETARA KAS PADA AKHIR BULAN & $\mathbf{1 , 2 0 0 , 0 0 0 , 0 0 0}$ \\
\hline
\end{tabular}

Gambar 9.Laporan Arus Kas

Sumber : Gereja

e. Catatan Atas Laporan Keuangan

Catatan atas laporan keuangan merupakan bagian tak terpisahkan dari laopran keuangan gereja. Catatan atas laporan keuangan memuat penjelasan mengenai gambaran umum masjid, ikthisar kebijakan akuntasi, penjelasan pos-pos laporan keuangan dan informasi penting lainnya. Catatan atas laporan keuangan disajikan secara sistematis. Setiap pos dalam laporan posisi keuangan, laporan penghasilan komprehensif, dan laporan arus kas harus berkaitan dengan informasi yang ada dalam catatan atas laporan keuangan.

f. Neraca Saldo Setelah Penutupan

Neraca saldo setelah penutupan adalah saldo akhir suatu periode pencatatan akuntansi yang akan menjadi neraca awal diperiode selanjutnya. Neraca saldo akhir merupakan neraca saldo yang dibuat setelah akun nominal ditutup sehingga yang tinggal dalam neraca saldo akhir adalah akun rill saja. Berikut neraca saldo periode januari 2020 yang akan digunakan untuk neraca saldo awal periode berikutnya yaitu Februari 2020 :

\section{GEREJA HKBP KM 55}

Neraca Saldo Setelah Penutupan

\begin{tabular}{|l|l|l|}
\hline & Per & $\mathbf{3 1 - 0 1 - 2 0}$ \\
\hline Aset & & \\
\hline ASET LANCAR & & \\
\hline Kas dan setara kas & $1,200,000,000$ & \\
\hline Perlengkapan gereja & $24,700,000$ & \\
\hline Perlengkapan pendidikan/ tk/paud HKBP & $1,200,000$ & \\
\hline ASET TIDAK LANCAR & & \\
\hline Tanah & $8,157,013,500$ & \\
\hline Bangunan gereja HKBP & $1,200,000,000$ & \\
\hline Ak. Penyusutan bangunan gereja HKBP & & $890,900,000$ \\
\hline Bangunan tk/paud HKBP & $800,000,000$ & \\
\hline Ak. Penyusutan bangunan tk/paud HKBP & & $450,000,000$ \\
\hline Peralatan gereja & $250,000,000$ & \\
\hline Ak. Penysutan peralatan gereja & & $78,000,000$ \\
\hline Peralatan tk/paud HKBP & $4,300,000,000$ & \\
\hline Ak. Penyusutan peralatan tk/paud HKBP & & $2,200,000,000$ \\
\hline LIABILITAS & & \\
\hline
\end{tabular}

JURNAL ILMIAH KOMPUTERISASI AKUNTANSI Vol. 14, No. 2, Desember $2021: 308-339$ 
JURNAL ILMIAH KOMPUTERISASI AKUNTANSI p-ISSN : 1979-116X e-ISSN : 2614-8870 •

\begin{tabular}{|l|l|l|} 
Utang entitas & - & \\
\hline Titipan & - & \\
\hline ASET NETO & & \\
\hline Aset neto tanpa pembatasan & & $51,103,500$ \\
\hline Aset neto dengan pembatasan & & $12,262,910,000$ \\
\hline Total & $\mathbf{1 5 , 9 3 2 , 9 1 3 , 5 0 0}$ & $\mathbf{1 5 , 9 3 2 , 9 1 3 , 5 0 0}$ \\
\hline
\end{tabular}

Gambar 10. Neraca Saldo Setelah Penutupan

Sumber : Gereja

\section{Kesimpulan dan Saran}

\subsection{Kesimpulan}

Berdasarkan analisis dan uraian masalah pada bab sebelumnya, maka dapat penulis simplkan beberapa sebagai berikut:

1. Penyusunan laporan Penghasilan Komprehensif yang memperlihatkan kenaikan dan penurunan dari asset neti, Laporan Posisi Keuangan yang memperlihatkan nilai dari asset, kewajiban serta asset neto Gereja HKBP KM 55 per 31 Januari dan 29 Februaru, Laporan Arus Kas yang berisi penggunaan kas dari aktivitas operasi, aktivitas pendanaan serta aktivitas investasi dan Catatan Atas Laporan Keuangan Gereja HKBP KM 55 yang berisi informasi umum, kebijakan akuntansi serta rincian perhitungan untuk setiap akun yang dimiliki Gereja HKBP KM 55.

2. Penyusunan laporan Keuangan berdasarkan ISAK N0. 35 dapat menyajikan perubahan asset neto, dan menyajikan naik turunnya asset neto selama periode tertentu, sehingga ini bisa disajikan sebagai penilaian kinerja Gereja HKBP KM 55. Selain itu juga dapat menyajikan laporan arus kas Gereja periode tertentu, yang melaporkan penerimaan dan pengeluaran kas selama periode tertentu. Berikut hasil kinerja Gereja HKBP KM 55:

a. Bulan Januari 2020

1. Penurunan Aset Neto bulan Januari 2020 sebesar Rp. 3.006.500

2. Total Aset Neto Akhir Tanpa Pembatasan per 31 Januari 2020 adalah Rp. 51.103.500

3. Total Aset Neto Akhir Dengan Pembatasan per 31 Januari 2020 adalah Rp. 12.262.910.000

4. Posisi Keuangan per 31 Januari 2020 adalah Rp. 12.314.013.500

5. Kenaikan Neto dalam Kas sebesar Rp. 17.373 .500

6. Kas Akhir per 31 Januari 2020 adalah Rp. 1.200.000.000

\subsection{Saran}

Dengan adanya penelitian ini diharapkan pihak Gereja HKBP KM 55 dapat mencatat pelaporan keuangan sesuai dengan standar yang berlaku yaitu ISAK 35 tujuannya agar kita bisa melihat bagaimana laporan posisi keuangan Gereja yang sebenarnya.

Penyajian Laporan Keuangan Entitas Berorientasi Non Laba Berdasarkan ISAK 35 Pada Gereja HKBP Km 55 (Sahala Purba) 


\section{Daftar Pustaka}

1. Santoso,Hendra F 2001. Public Sector Accounting volume 7.yogyakarta:Indonesia

2. Andarsari,Pipit Rosita 2016. Jurnal Ekonomi Universitas Kadiri volume 1.Kediri:Indonesia

3. Nofianti,Leny 2012. Kajian Filolosofis Akuntansi:Seni,Ilmu atau Teknologi volume 4.Riau:Indonesia

4. Entrepreneur, J. (2018). Diambil kembali dari https://www.jurnal.id/id/blog/2018-kenali-setiapjenis-aset-yang-anda-miliki/.

5. IAI, D. (2018, Desember 31). Diambil kembali dari http://iaiglobal.or.id/v03/files/file_berita/DE\%20ISAK\%2035.pdf.

6. Primantoro, T. (2018, Oktober 16). Diambil kembali dari https://www.academia.edu/37618789/Liabilitas.

7. Sukma Diviana, R. P., \& Armel Yentifa, Zahara, Azi Siswanto. (2020). PENYAJIAN LAPORAN KEUANGAN ENTITAS BERORIENTASI NONLABA BERDASARKAN ISAK 35 PADA MASJID BAITUL HAADI. Jurnal Akuntansi dan Manajemen, 15(2), 113-132 
Variabel-variabel yang digunakan dalam penelitian ini adalah sebagai berikut:

a. Variabel bebas (independen variable). Variabel bebas adalah variabel yang mempengaruhi atau yang menjadi sebab perubahannya atau timbulnya variabel dependen atau terikat (Sugiyono, 2009). Variabel independen dalam penelitian ini adalah variabel Profitabilitas (X1) yang diproxikan dengan ROA, Leverage (X2), Ukuran Perusahaan (X3), dan Likuiditas (X).

Profitabilitasmerupakan gambaran kinerja keuangan perusahaan dalam menghasilkan laba dari pengelolaan aktiva yang dikenal dengan Return On Asset (ROA). ROA merupakan suatu indikator yang mencerminkan performa keuangan perusahaan. Pengukuran kinerja dengan ROA menunjukkan kemampuan menghasilkan laba dari aktiva yang dimiliki. ROA diukur dengan menggunakan proksi pada model Lanis dan Richardson (2012) yaitu sebagai berikut:

$$
\mathrm{ROA}=\frac{\text { Pendapatan Sebelum Pajak }}{\text { Tntal Aset }}
$$

Leverage merupakan tingkat hutang yang digunakan perusahaan dalam melakukan pembiayaan. Leverage menggambarkan tingkat risiko dari perusahaan yang diukur dengan membandingkan total kewajiban perusahaan dengan total aktiva yang dimiliki perusahaan. Leverage adalah rasio yang mengukur kemampuan utang baik jangka panjang maupun jangka pendek untuk membiayai aset perusahaan (Waluyo dkk, 2015). Leverage diukur dengan menggunakan rumus sebagai berikut :

$$
\text { LEV }=\frac{\text { Hutang Jangka Panjang }}{\text { Trtal Aset. }}
$$

Ukuran Perusahaanadalah ukuran perusahaan yang besarnya di hitung dari besarnya logaritma total aset yang dimiliki perusahaan (Rusydi, 2013). Penggunaan natural log (Ln) dalam penelitian ini dimaksudkan untuk mengurangi fluktuasi data yang berlebihan tanpa mengubah proporsi dari nilai asal yang sebenarnya (Waluyo dkk, 2015). Ukuran perusahaan dapat diukur dengan menggunakan rumus :

$$
\text { Ukuran Perusahaan }=\operatorname{Ln} \text { (Total Aset) }
$$

Likuiditas didefinisikan sebagai ukuran dalam menilai kemampuan sebuah perusahaan untuk memenuhi kewajiban jangka pendek dan kemampuan perusahaan dalam menghadapi kondisi mendesak yang memerlukan dana ( Kieso et al, 2009 ) dalam Tiaras dan Henryanto (2015). Perusahaan dengan rasio likuditas yang tinggi menunjukkan tingginya kemampuan perusahaan dalam memenuhi utang jangka pendeknya, yang menandakan bahwa perusahaan dalam kondisi keuangan yang sehat. Rasio likuiditas diukur dengan :

$$
\text { Rasio Lancar }=\frac{\text { aktiva lancar }}{\text { kewajibanlancar }}
$$

b. Variabel terikat (Dependen Variable). Variabel terikat adalah variabel yang dipengaruhi atau yang menjadi akibat karena adanya variabel bebas (Sugiyono, 2009).

Variabel dependen dalam penelitian ini adalah Agresivitas Pajak yang diukur menggunakan Effective Tax Rate (ETR). Effective Tax Rate (ETR) dihitung dengan menggunakan beban pajak penghasilan terhadap laba perusahaan sebelum pajak, yang di peroleh darilaporan laba rugi perusahaan tahun berjalan. Beban pajak penghasilan merupakan penjumlahan beban pajak kini dan beban pajak tangguhan. ETR yang rendah menunjukan beban pajak penghasilan lebih kecil dari pada dari pendapatan sebelum pajak. ETR dapat dihitung menggunakan rumus yang digunakan oleh Lanis dan Richardson (2012) sebagai berikut:

$$
\text { ETR }=\frac{\text { Beban Pajak Penghasilan }}{\text { Laba Sebelum pajak }}
$$

Penyajian Laporan Keuangan Entitas Berorientasi Non Laba Berdasarkan ISAK 35 Pada Gereja HKBP Km 55 (Sahala Purba) 


\section{Objek Penelitian, Unit Sampel, Populasi, dan Penentuan Sampel}

Obyek dalam penelitian adalah perusahaan makanan dan minuman yang terdaftar di Bursa Efek Indonesia (BEI) pada tahun 2016-2019. Yang selama 4 tahun berturut - turut mempublikasikan laporan keuangan secara lengkap dan sudah diaudit serta stabil di Bursa Efek Indonesia (belum pernah keluar dari BEI).

Populasi adalah wilayah generalisasi yang terdiri atas obyek/subyek yang mempunyai kualitas dan karakteristik tertentu yang ditetapkan oleh peneliti untuk dipelajari dan kemudian ditarik kesimpulannya (Sugiyono, 2009). Populasi dalam penelitian ini adalah perusahaanperusahaan makanan dan minuman yang terdaftar di BEI tahun pengamatan 2016 sampai dengan 2019. Berdasarkan info dari situs resmi Bursa Efek Indonesia di www.idx.co.id perusahaan go publik sektor makanan dan minuman berjumlah 29 perusahaan tetapi dari 29 perusahaan, 1 perusahaan keluar dari BEI karena sudah tidak going concern dan 2 perusahaan berpindah sektor usaha. Sehingga populasi yang ada sebanyak 27 Perusahaan.

Sampel adalah bagian dari jumlah dan karakteristik yang dimiliki oleh populasi tersebut (Sugiyono, 2009). Kriteria tersebut adalah: (1) Perusahaan-perusahaan makanan dan minumam yang terdaftar di Bursa Efek Indonesia tahun 2016-2019. (2) Mempublikasikan laporan tahunan (annual reprot) dan laporan keuangan (financial report) dari tahun 2016 - 2019 yang diakses melalui website perusahaan atau website BEI dan mengandung informasi laporan berkelanjutan.(3) Perusahaan dengan data keuangan yang lengkap dengan menggunakan satuan nilai rupiah. (4) Perusahaan yang tidak mengalami kerugian selama tahun penelitian. (5) Memiliki data yang lengkap sesuai dengan variabel-variabel yang digunakan dalam penelitian. (6) Memiliki ETR antara 0-1, dimana semakin rendah nilai ETR (mendekati 0) maka semakin tinggi agresivitas pajaknya.

\section{Hasil dan Pembahasan}

Adapun yang digunakan dalam penelitian ini yaitu data sekunder yang berasal dari annual report dan laporan keuangan tahunan pada tahun 2016 - 2019 yang terdaftar di Bursa Efek Indonesia (BEI) dengan menggunduh data tersebut di website resmi Bursa Efek Indonesia (BEI) pada alamat website www.idx.co.id. Berikut ini adalah rincian perolehan sampel perusahaan makanan dan minuman yang terdaftar di Bursa Efek Indonesia dengan kriteria - kriteria yang telah ditentukan sesuai dengan kebutuhan analisis sebagai berikut :

Tabel 1 data sampel perusahaan

\begin{tabular}{|c|l|c|}
\hline No. & \multicolumn{1}{|c|}{ Keterangan } & Perusahaan \\
\hline 1 & $\begin{array}{l}\text { Perusahaan makanan dan minuman yang } \\
\text { terdaftar di Bursa Efek Indonesia dari tahun } \\
2016-2019\end{array}$ & 29 \\
\hline 2. & $\begin{array}{l}\text { Perusahaan yang tidak melaporkan laporan } \\
\text { keuangan tahunan selama periode penelitian } \\
\text { tahun 2016-2019 }\end{array}$ & $(11)$ \\
\hline 3. & $\begin{array}{l}\text { Perusahaan yang delisting karena tidak going } \\
\text { concern maupun pindah ke sektor lain }\end{array}$ & $(3)$ \\
\hline 4. & $\begin{array}{l}\text { Perusahaan yang tidak memiliki profitabilitas } \\
\text { positif }\end{array}$ & \\
\hline 5. & $\begin{array}{l}\text { Perusahaan yang tidak menggunakan satuan } \\
\text { nilai rupiah dalam laporan keuangan }\end{array}$ \\
\hline
\end{tabular}

JURNAL ILMIAH KOMPUTERISASI AKUNTANSI Vol. 14, No. 2, Desember 2021 : $308-339$ 


\begin{tabular}{|c|l|c|}
\hline 5. & Tidak memiliki nilai ETR 0-1 & - \\
\hline 6. & Perusahaan sampel & 12 \\
\hline 7. & Lama Penelitian & 4 Tahun \\
\hline 8. & Data observasi selama 4 tahun x 12 (sampel) & 48 \\
& & \\
\hline
\end{tabular}

\section{Uji Statistik Deskriptif}

Variabel - variabel yang digunakan dalam penelitian ini yaitu likuiditas, leverage, profitabilitas, ukuran perusahaan, dan capital intensity sebagai variabel independen. Sedangkan variabel dependen yang digunakan adalah agresivitas pajak menggunakan proksi effective tax rate. Variabel - variabel tersebut akan diuji secara statistik deskriptif. Pengujian dengan statistik deskriptif akan memberikan gambaran atau deskripsi data yang dilihat dari nilai minimal, maksimal, rata - rata (mean) dan standar deviasi. Berikut ini merupakan tabel hasil pengujian statistik deskriptif atas variabel - variabel tersebut :

Tabel 2

Hasil uji statistik deskriptif

\begin{tabular}{lrrrrr}
\hline \multicolumn{7}{c}{ Descriptive Statistics } \\
\hline N & \multicolumn{1}{c}{ Minimum } & Maximum & Mean & Std. Deviation \\
\hline LIK & 48 & .51 & 8.64 & 2.3113 & 1.69067 \\
\hline REV & 48 & .15 & .75 & .4619 & .14911 \\
SIZE & 48 & .03 & .88 & .1717 & .15547 \\
\hline ETR & 48 & 14.39 & 30.19 & 22.9456 & 5.70225 \\
\hline Valid N (listwise) & 48 & .13 & .35 & .2533 & .03986 \\
\hline S & 48 & & & &
\end{tabular}

Sumber : data sekunder yang diolah SPSS

a. Variabel Independen

Variabel Likuiditas, Hasil uji statistik pada tabel 2 menunjukkan bahwa variabel likuiditas dari jumlah sampel 48 memiliki nilai minimal sebesar 0,51 dan nilai maksimal sebesar 8,64 dengan nilai rata - rata (mean) sebesar 2,3113, sedangkan standar deviasi sebesar 1,69067. 
Variabel Leverage Hasil uji statistik pada tabel 2 menunjukkan bahwa variabel leverage dari jumlah sampel 48 memiliki nilai minimal sebesar 0,15 dan nilai maksimal sebesar 0,75 dengan nilai rata - rata (mean) sebesar 0,4619 , sedangkan standar deviasi sebesar 0,14911 .

Variabel Profitabilitas Hasil uji statistik pada tabel 2 menunjukkan bahwa variabel profitabilitas dari jumlah sampel 48 memiliki nilai minimal sebesar 0,03 dan nilai maksimal sebesar 0,88 dengan nilai rata - rata (mean) sebesar 0,1717 , sedangkan standar deviasi sebesar 0,15547 .

Variabel Ukuran Perusahaan, Hasil uji statistik pada tabel 2 menunjukkan bahwa variabel ukuran perusahaan dari jumlah sampel 48 memiliki nilai minimal sebesar 14,39 dan nilai maksimal sebesar 30,19 dengan nilai rata - rata (mean) sebesar 22,9456, sedangkan standar deviasi sebesar 5,70225.

b. Variabel Dependen

Variabel dependen dalam penelitian ini adalah agresivitas pajak yang diukur dengan effective tax rate. Hasil uji statistik pada tabel 2 menunjukkan bahwa variabel effective tax rate dari jumlah sampel 48 memiliki nilai minimal sebesar 0,13 dan nilai maksimal sebesar 0,35 dengan nilai rata - rata (mean) sebesar 0,2533, sedangkan standar deviasi sebesar 0,03986 .

\section{Uji Multikolinearitas}

Pengujian multikolinearitas bertujuan untuk menguji apakah model regresi ditemukan adanya korelasi antar variabel bebas (independen). Pengujian multikolinearitas pada penelitian ini dilakukan dengan melihat nilai tolerance dan Variance Inflation Factor (VIF). Hasil pengujian multikolinearitas dapat diketahui pada tabel berikut :

Tabel 3 Hasil Uji Multikolinearitas

\begin{tabular}{l|l|r|}
\begin{tabular}{|l|r|r|}
\multicolumn{2}{|c|}{ Tolerance } & \multicolumn{1}{c|}{ VIF } \\
\hline 1 & .279 & 3.582 \\
\cline { 2 - 3 } & .246 & 4.067 \\
\cline { 2 - 3 } & .736 & 1.358 \\
\cline { 2 - 3 } & .600 & 1.668 \\
\hline
\end{tabular} \\
Sumber : data sekunder yang diolah SPSS
\end{tabular}

Dari hasil perhitungan hasil analisis data diatas, diperoleh nilai VIF untuk seluruh variabel bebas $<10$ dan tolerance $>0,10$. Hal ini dapat disimpulkan bahwa model regresi tersebut bebas dari multikolinearitas

\section{Uji Autokorelasi}

Uji autokorelasi adalah untuk melihat apakah terjadi korelasi antara suatu periode $t$ dengan periode sebelumnya (t-1). Uji autokorelasi dapat dilakukan dengan menggunakan uji DurbinWatson (DW), dimana hasil pengujian ditentukan berdasarkan nilai Durbin-Watson (DW).

Tabel 4 Hasil Uji Autokorelasi

JURNAL ILMIAH KOMPUTERISASI AKUNTANSI Vol. 14, No. 2, Desember $2021: 308-339$ 


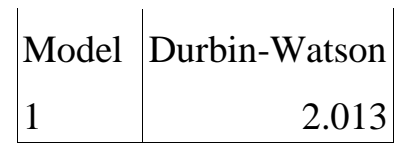

Sumber : data sekunder yang diolah SPSS

Hasil uji asumsi autokorelasi dimana diperoleh nilai Durbin-Watson sebesar 2,013. Hasil nilai Durbin-Watson tersebut apabila dibandingkan dengan tabel Durbin-Watson untuk sampel 48 dengan derajat kepercayaan 95\%, maka nilai DW berada pada rentang nilai du sebesar 1,7725 dan nilai 4-du sebesar 2,2275. Oleh karena itu dapat dikatakan bahwa model regresi dalam penelitian ini terbebas dari problem autokorelasi.

\section{Uji Heterokedastisitas}

Uji Heteroskedastisitas bertujuan menguji apakah dalam model regresi terjadi ketidaksamaan variance dari residual satu pengamatan ke pengamatan yang lain.

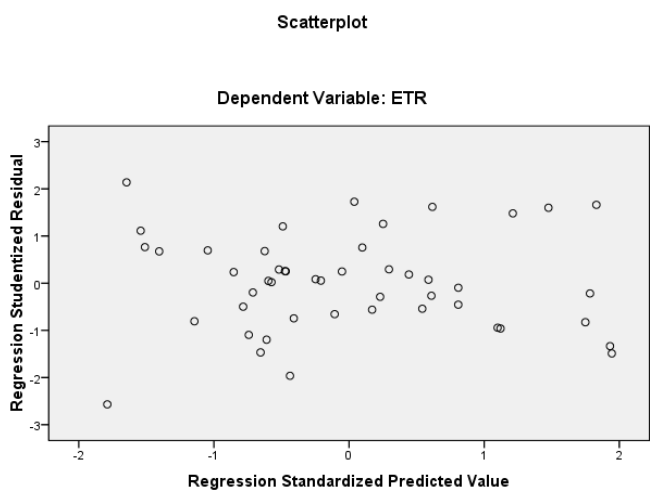

Gambar 1 Hasil Heteroskedastisitas

Sumber : data sekunder yang diolah SPSS

Berdasarkan hasil uji heteroskedastisitas melalui diagram Scatterplot pada gambar 1, dapat disimpulkan bahwa model regresi dalam penelitian ini tidak terjadi heteroskedastisitas. Kesimpulan ini diperoleh dengan melihat titik-titik yang menyebar secara acak baik diatas maupun dibawah angka 0 pada sumbu Y pada diagram Scatterplot.

\section{Uji Regresi Linier}

Analisis regresi linier berganda bertujuan untuk mengetahui pengaruh likuiditas, leverage, profitabilitas, ukuran perusahaan terhadap agresivitas pajak. Hasil analisis regresi linier berganda adalah sebagai berikut:

Tabel 5 Hasil Uji Regresi Linier

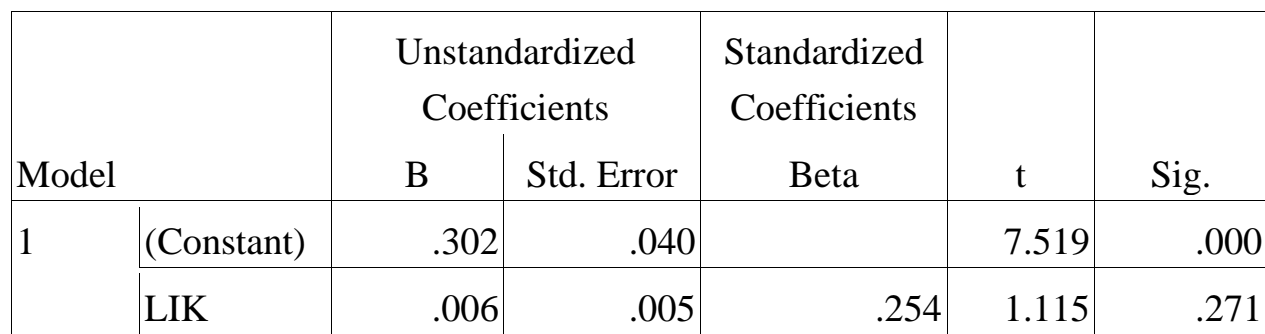

Penyajian Laporan Keuangan Entitas Berorientasi Non Laba Berdasarkan ISAK 35 Pada Gereja HKBP Km 55 (Sahala Purba) 


\begin{tabular}{|l|l|r|r|r|r|r|}
\hline \multirow{2}{*}{ LEV } & .164 & .065 & .614 & 2.524 & .015 \\
\cline { 2 - 7 } & ROA & -.106 & .036 & -.414 & -2.946 & .005 \\
\cline { 2 - 6 } & SIZE & -.005 & .001 & -.751 & -4.825 & .000 \\
\hline
\end{tabular}

Dari hasil analisis regresi, maka diperoleh persamaan sebagai berikut :

$$
\text { ETR }=0,302+0,006 \mathrm{LIK}+0,164 \mathrm{LEV}-0,106 \mathrm{ROA}-0,005 \mathrm{SIZE}
$$

Berdasarkan persamaan linier diatas, analisis regresi berganda dapat di interpretasikan sebagai berikut :

a. Nilai konstanta sebesar 0,302 menyatakan bahwa agresivitas pajak (Y) yaitu jika variabel likuiditas, leverage, profitabilitas, ukuran perusahaan tidak ada atau tidak bernilai sama dengan nol maka nilai agresivitas pajak sebesar 0,302.

b. Nilai koefisien untuk variabel likuiditas diketahui sebesar 0,006 yang memiliki arah positif. Artinya bahwa apabila likuiditas meningkat sebesar 1 persen, maka menaikkannilai agresivitas pajak sebesar 0,006 .

c. Nilai koefisien untuk variabel leverage diketahui sebesar 0,164 yang memiliki arah positif. Artinya bahwa apabila leverage meningkat sebesar 1 persen, maka akan meningkat nilai agresivitas pajak sebesar 0,164 .

d. Nilai koefisien untuk variabel profitabilitas diketahui sebesar -0,106 yang memiliki arah negatif. Artinya bahwa apabila profitabilitas meningkat sebesar 1 persen, maka akan menurunkan nilai agresivitas pajak sebesar $-0,106$.

e. Nilai koefisien untuk variabel ukuran perusahaan diketahui sebesar -0,005 yang memiliki arah negatif. Artinya bahwa apabila ukuran perusahaan meningkat sebesar 1 persen, maka akan menurunkan nilai agresivitas pajak sebesar -0,005.

\section{Uji Koefisien Determinasi $\left(\mathbf{R}^{2}\right)$}

Nilai koefisien determinasi menunjukkan persentase variasi nilai variabel independen yang dapat dijelaskan oleh persamaan regresi yang dihasilkan.

Tabel 6 Hasil Uji Koefisien Determinasi $\left(\mathrm{R}^{2}\right)$

\begin{tabular}{|l|r|r|r|r|}
\hline Model & R & R Square & $\begin{array}{c}\text { Adjusted R } \\
\text { Square }\end{array}$ & $\begin{array}{c}\text { Std. Error of } \\
\text { the Estimate }\end{array}$ \\
\hline 1 & $.612^{\mathrm{a}}$ & .375 & .317 & .03295 \\
\hline
\end{tabular}

Dari tabel 6 di atas menunjukkan bahwa nilai Adjusted R Square $\left(\mathrm{R}^{2}\right)$ sebesar 0,317 yang berarti bahwa variabel dependen yang dapat dijelaskan oleh variabel independen sebesar 0,317 atau $31,7 \%$. Hal ini berarti $31,7 \%$ tindakan agresivitas pajak dipengaruhi variabel likuiditas, leverage, profitabilitas, ukuran perusahaan. Sedangkan sisanya 68,3\% dipengaruhi oleh variabel lain yang tidak diteliti dalam penelitian ini.

\section{Uji Signifikansi Simultan (Uji Statistik F)}

JURNAL ILMIAH KOMPUTERISASI AKUNTANSI Vol. 14, No. 2, Desember $2021: 308-339$ 
Uji F menunjukkan apakah model regresi fit untuk diolah lebih lanjut. Uji ini untuk melihat pengaruh variabel likuiditas, leverage, profitabilitas, dan ukuran perusahaan secara simultan atau bersama-sama terhadap agresivitas pajak. Hasil Uji F dapat diketahui sebagai berikut :

Tabel 7 Hasil Uji Anova

ANOVA $^{b}$

\begin{tabular}{|c|c|c|c|c|c|c|}
\hline \multicolumn{2}{|c|}{ Model } & $\begin{array}{l}\text { Sum of } \\
\text { Squares }\end{array}$ & df & Mean Square & $\mathrm{F}$ & Sig. \\
\hline \multirow[t]{3}{*}{1} & Regression & .028 & 4 & .007 & 6.446 & $.000^{\mathrm{a}}$ \\
\hline & Residual & .047 & 43 & .001 & & \\
\hline & Total & .075 & 47 & & & \\
\hline
\end{tabular}

Sumber : data sekunder yang diolah SPSS

Berdasarkan data tabel 7 terlihat bahwa nilai $F$ sebesar 4,636 dengan tingkat hasil signifikansi sebesar 0,002. Hasil tersebut berada dibawah tingkat probabilitas yang ditentukan yaitu 0,05 , maka variabel likuiditas, leverage, profitabilitas, dan ukuran perusahaan berpengaruh secara serentak (simultan) pada tingkat agresivitas pajak perusahaan.

\section{Hasil Uji Hipotesis ( Uji t )}

\section{Pengaruh Likuiditas Terhadap Agresivitas Pajak}

Hipotesis pertama dalam penelitian ini adalah likuiditas berpengaruh terhadap agresivitas pajak. Hasil uji t menunjukkan bahwa nilai signifikansi pada variabel likuiditas sebesar 0,271. Nilai tersebut menunjukkan bahwa nilai sig. 0,271 $>\alpha=0,05$ dan diperoleh nilai t-hitung sebesar 1,115. Dapat disimpulkan bahwa likuiditas tidak berpengaruh terhadap agresivitas pajak dan hipostesis pertama ditolak.

Dan berdasarkan pada pengujian hipotesis pertama yang merumuskan bahwa Likuiditas berpengaruh terhadap agresivitas pajak perusahaan, setelah dilakukan pengujian ternyata Likuiditas tidak berpengaruh secara signifikan terhadap agresivitas pajak dengan nilai signifikansi 0,271 yang mempunyai nilai lebih besar dari 0,05 . Hasil penelitian sejalan sejalan dengan penelitian Tiaras dan Wijaya (2015) yang membuktikan bahwa likuiditas tidak berpengaruh terhadap agresivitas pajak.

\section{Pengaruh Leverage Terhadap Agresivitas Pajak}

Hipotesis kedua dalam penelitian ini adalah leverage berpengaruh terhadap agresivitas pajak. Hasil uji t pada tabel diatas menunjukkan bahwa nilai signifikansi pada variabel leverage sebesar 0,015. Nilai tersebut menunjukkan bahwa nilai sig. $0,015<\alpha=0,05$ diperoleh nilai thitung sebesar 2,524. Dapat disimpulkan bahwa leverage berpengaruh terhadap agresivitas pajak dan hipotesis kedua diterima.

Pengujian hipotesis kedua yang merumuskan bahwa terdapat pengaruh variabel leverage terhadap agresivitas pajak perusahaan dan setelah diuji, ternyata terdapat pengaruh yang signifikan pada variabel terhadap agresivitas pajak perusahaan dengan nilai signifikansi 0,015 yang mempunyai nilai lebih kecil dari 0,05 . Kemudian penelitian yang dilakukan Tiaras dan Wijaya (2015) dan Mustika (2017) yang menghasilkan bukti leverage tidak berpengaruh berarti

Penyajian Laporan Keuangan Entitas Berorientasi Non Laba Berdasarkan ISAK 35 Pada Gereja HKBP Km 55 (Sahala Purba) 
bahwa semakin tinggi leverage maka agresivitas pajak pada perusahaan akan semakin rendah. Ketika perusahaan lebih banyak mengandalkan pembiayaan dari hutang daripada pembiayaan yang berasal dari ekuitas untuk operasinya, maka perusahaan akan memiliki ETR yang lebih rendah.

\section{Pengaruh Return On Assets Terhadap Agresivitas Pajak}

Hipotesis ketiga dalam penelitian ini adalah profitabilitas berpengaruh terhadap agresivitas pajak. Hasil uji t pada tabel diatas menunjukkan bahwa nilai signifikansi pada variabel profitabilitas yang diproksikan dengan ROA sebesar 0,005. Nilai tersebut menunjukkan bahwa nilai sig. $0,005<\alpha=0,05$ diperoleh nilai t-hitung sebesar -2,946. Dapat disimpulkan bahwa profitabilitas berpengaruh terhadap agresivitas pajak dan hipotesis ketiga diterima.

Hipotesis ketiga yang merumuskan bahwa terdapat pengaruh antara variabel profitabilitas dengan agresivitas pajak perusahaan dan setelah diuji, hasil penelitian ini berhasil menemukan hubungan signifikan antara variabel profitabilitas dengan agresivitas pajak perusahaan dengan nilai signifikansi yang diperoleh sebesar 0,005 lebih kecil dari nilai signifikansi sebesar 0,05 yang memberikan kesimpulan bahwa hipotesis diterima. Semakin besar keuntungan yang diperoleh maka semakin besar pajak yang harus dibayarkan. Dengan kata lain pada saat profitabilitas perusahaan tinggi maka dapat meningkatkan agresivitas pajak dengan cara menekan nilai ETR menjadi lebih rendah. Penelitian ini sesuai dengan penelitian yang dilakukan oleh Napitu dan Kurniawan (2016) dan Jaya (2018) yang menyatakan bahwa ROA memiliki pengaruh terhadap agresivitas pajak.

\section{Pengaruh Ukuran Perusahaan Terhadap Agresivitas Pajak}

Hipotesis keempat dalam penelitian ini adalah ukuran perusahaan berpengaruh terhadap agresivitas pajak. Hasil uji t pada tabel diatas menunjukkan bahwa nilai signifikansi pada variabel ukuran perusahaan sebesar 0,000 diperoleh nilai t-hitung sebesar $-4,825$. Nilai tersebut menunjukkan bahwa nilai sig. $0,000<\alpha=0,05$. Dapat disimpulkan bahwa ukuran perusahaan berpengaruh terhadap agresivitas pajak dan hipotesis keempat diterima.

Pengujian hipotesis keempat yang merumuskan bahwa terdapat pengaruh antara variabel ukuran perusahaan dengan agresivitas pajak perusahaan dan setelah diuji, menemukan adanya hubungan signifikan antara variabel ukuran perusahaan dengan agresivitas pajak perusahaan dengan nilai signifikansi yang diperoleh sebesar 0,000 dengan nilai signifikansi lebih kecil dari 0,05 sehingga hipotesis diterima. Yang artinya, antara variabel ukuran perusahaan dengan agresivitas pajak memiliki pengaruh antara keduanya. Perusahaan yang termasuk dalam skala perusahaan besar akan mempunyai sumber daya yang berlimpah yang dapat digunakan untuk tujuan-tujuan tertentu. Sumber daya yang dimiliki perusahaan dapat digunakan oleh manajer untuk memaksimalkan kinerja manajer dengan cara menekan pajak perusahaan.

Hasil penelitian ini sejalan dengan penelitian yang dilakukan oleh Tiaras dan Wijaya (2015), Napitu dan Kurniawan (2016), Rohmansyah (2017) dan Jaya (2018) yang menyatakan bahwa ukuran perusahaan memiliki pengaruh terhadap agresivitas pajak perusahaan. Perusahaan besar memiliki ruang lebih besar untuk melakukan perencanaan pajak. Semakin besar perusahaan, maka semakin besar pula total aktiva yang dimiliki. Total aktiva yang besar akan dimanfaatkan oleh perusahaan untuk melakukan agresivitas pajak.

\section{Kesimpulan}

Berdasarkan hasil pengujian dan analisis yang telah dilakukan, serta pembahasan yang dilakukan, maka dapat ditarik beberapa kesimpulan sebagai berikut: 
1. Likuiditas berpengaruh negatif terhadap agresivitas pajak. Hal ini ditunjukkan pada koefisien regresi dari likuiditas memiliki tanda negatif, maka hubungan antara likuiditas terhadap effective tax rate adalah meningkatnya nilai likuiditas perusahaan akan menurunkan nilai effective tax rate sehingga agresivitas pajak perusahaan meningkat. Sehingga dapat disimpulkan dengan likuiditas yang baik perusahaan makanan dan minuman tidak menjadikan pajak sebagai tujuan untuk meminimalisasi biaya. Selain itu, likuiditas yang terlalu menggambarkan tingginya uang tunai yang mengganggur sehingga dianggap kurang produktif. Tetapi jika likuiditas terlalu rendah maka akan mengurangi tingkat kepercayaan kreditur terhadap perusahaan dan bisa berakibat pinjaman modal oleh para kreditur menurun.

2. Leverage berpengaruh positif terhadap agresivitas pajak. Hal ini ditunjukkan pada koefisien regresi dari leverage memiliki tanda positif, maka hubungan antara leverage terhadap effective tax rate adalah meningkatnya nilai leverage perusahaan akan menaikkan nilai effective tax rate sehingga agresivitas pajak perusahaan menurun. Sehingga dapat disimpulkan perusahaan akan menggunakan utang yang diperoleh untuk keperluan investasi sehingga menghasilkan pendapatan di luar usaha perusahaan. Hal ini membuat laba yang diperoleh perusahaan naik dan mempengaruhi kenaikan beban pajak yang ditanggung perusahaan.

3. Retur on Asset berpengaruh positif terhadap agresivitas pajak. Hal ini ditunjukkan pada koefisien regresi dari return on assets memiliki tanda positif, maka hubungan antara return on assets terhadap effective tax rate adalah meningkatnya nilai return on assets perusahaan akan menaikkan nilai effective tax rate sehingga agresivitas pajak perusahaan menurun. Semakin besar keuntungan yang diperoleh maka semakin besar pajak yang harus dibayarkan. Dengan kata lain pada saat profitabilitas perusahaan tinggi maka dapat meningkatkan agresivitas pajak dengan cara menekan nilai ETR menjadi lebih rendah.

4. Ukuran perusahaan berpengaruh positif terhadap agresivitas pajak. Hal ini ditunjukkan pada koefisien regresi dari ukuran perusahaan memiliki tanda positif, maka hubungan antara ukuran perusahaan terhadap effective tax rate adalah meningkatnya nilai ukuran perusahaan akan menaikkan nilai effective tax rate sehingga agresivitas pajak perusahaan menurun. Dapat disimpulkan bahwa perusahaan yang termasuk dalam skala perusahaan besar akan mempunyai sumber daya yang berlimpah yang dapat digunakan untuk tujuan-tujuan tertentu. Sumber daya yang dimiliki perusahaan dapat digunakan oleh manajer untuk memaksimalkan kinerja manajer dengan cara menekan pajak perusahaan

\section{Daftar Pustaka}

[1] Ahmad Tabrani, Jamaluddin, Fudoli, 2020, Analisis Faktor yang Mempengaruhi Agresivitas Pajak (Studi Empiris pada Perusahaan LQ45 yang Terdaftar di Bursa Efek Indonesia Tahun 2015-2018), Jurnal REKOMEN (Riset Ekonomi Manajemen) Vol 4 No 1 2020, https://jurnal.untidar.ac.id/index.php/rekomen/article/view/2440

[2] Army Thesa Napitu, Christophorus Heni Kurniawan, 2016, Analisis Faktor-Faktor yang Mempengaruhi Agresivitas Pajak Perusahaan ManufakturSimposium Nasional Akuntansi XIX,

Lampung, http://lib.ibs.ac.id/materi/Prosiding/SNA\%20XIX\%20(19)\%20Lampung\%202016/makalah 1148.pdf,

[3] Bursa Efek Indonesia. Laporan keuangan perusahaan tercatat. Diambil dari : https://www.idx.co.id/perusahaan-tercatat/laporan-keuangan-dan-tahunan/.

[4] Djeni Indrajati W, Sandy Djumena, Yuniarwati, 2017, Faktor-Faktor Yang Mempengaruhi Agresivitas Pajak Pada Perusahaan Manufaktur Yang Terdaftar Di BEI 2013-2015, Jurnal Muara Ilmu Ekonomi dan Bisnis Vol. 1, No. 1, April 2017: hlm 125-134, 
https://journal.untar.ac.id/index.php/jmieb/article/view/415

[5] Direktorat Jendral Pajak. "Undang - Undang RI nomor 36 tahun 2008". Diambil dari:http://ketentuan.pajak.go.id/index.php?r=aturan/rinci\&idcrypt=oJeko6A\%3D

[6] Fadli, Imam. 2016. Pengaruh Likuiditas, Leverage, Komisaris Independen, Manajemen Laba, dan Kepemilikan Institusional Terhadap Agresivitas Pajak Perusahaan (Studi Pada Perusahaan Manufaktur Yang Terdaftar Di Bursa Efek Indonesia Periode 2011-2013). Jurnal Online Mahasiswa Fakultas Ekonomi Universitas Riau, 3(1), pp.1205-1219. https://jom.unri.ac.id/index.php/JOMFEKON/article/view/11451

[7] Ghozali, Imam. 2006. Analisis Multivariate dengan Program SPSS. Edisi Ke 4. Badan Penerbit Universitas Diponegoro : Semarang.

[8] Ghozali, Imam. (2016). Aplikasi Analisis Multivariate dengan IBM SPSS 23. Semarang : Badan Penerbit Fakultas Ekonomi Universitas Diponegoro.

[9] Indriantoro, Nur dan Supomo, Bambang. 2009. “ Metodologi Penelitian Bisnis Untuk Akuntansi Dan Manajemen ". Yogyakarta : BPPE Yogyakarta.

[10] Jaya, Firman. 2018. "Pengaruh Likuiditas, Profitabilitas, Ukuran Perusahaan, Capital Intencity Dan Pengungkapan Corporate Social Responsibility Terhadap Agresivitas Pajak (Studi Empiris pada Perusahaan Sektor Perdagangan, Jasa dan Investasi yang Terdaftar di BEI 2013-2016)". Jurnal Online Mahasiswa (JOM) Bidang Ilmu Ekonomi 1.1. hal.1-15.

[11] Jessica, dan Toly, Agus Arianto. 2014. "Pengaruh Pengungkapan Corporate Social Responsibilty Terhadap Agresivitas Pajak ". Tax \& Accounting Review 4.1. https://www.neliti.com/id/publications/157616/pengaruh-pengungkapan-corporate-socialresponsibilty-terhadap-agresivitas-pajak

[12] Luke, Zulaeka, 2016, Analisis Faktor Yang Mempengaruhi Agresivitas Pajak, Jurnal Akuntansi \& Auditing Volume 13/No. 1 Tahun 2016 : 80-96, https://ejournal.undip.ac.id/index.php/akuditi/article/view/13875

[13] Nurul Herawati, Rahmawati, Bandi, dan Doddy Setiawan, 2019, Penelitian Penghindaran Pajak Di Indonesia, InFestasi : Jurnal Bisnis dan Akuntansi Vol. 15 No. 2 Desember 2019 Hal. 108 - 135, https://journal.trunojoyo.ac.id/infestasi/article/view/6006

[14] Purwanto, A., 2016. Pengaruh Likuiditas, Leverage, Manajemen Laba, Dan Kopensasi Rugi Fiskal Terhadap Agresivitas Pajak Perusahaan Pada Perusahaan Pertanian Dan Pertambangan Yang Terdaftar Di Bursa Efek Indonesia Periode 2011-2013. Jurnal Online Mahasiswa Fakultas Ekonomi Universitas Riau, 3(1), pp.580-594, https://jom.unri.ac.id/index.php/JOMFEKON/article/view/10452

[15] Putri, V. R., \& Putra, B. I. (2017). Pengaruh Profitability, Leverage, , Ukuran Perusahaan Dan Proporsi Kepemilikan Institusional Terhadap Tax Avoidance. Jurnal Manajemen Dayasaing, 19(1), 1-1, https://doi.org/10.23917/dayasaing.v19i1.5100

[16] Retno Pujilestari, Mustika Winedar, 2018, Pengaruh Karakter Eksekutif, Ukuran Perusahaan, Kualitas Audit, dan Komite Audit Terhadap Tax Avoidance, Jurnal Akuntansi dan Auditing Volume 15/No. 2 Tahun 2018: 204 - 220, https://ejournal.undip.ac.id/index.php/akuditi/article/view/25768

[17] Sugiyono. 2010. Metode Penelitian Pendidikan Pendekatan Kuantitatif, kualitatif, dan R\&D. Bandung: Alfabeta.

[18] Saham OK. "Sub Sektor makanan dan minuman BEI". Diambil dari : https://www.sahamok.com/emiten/sektor-industri-barang-konsumsi/sub-sektor-makananminuman/. (20 November 2018).

[19] Suriana AR Mahdi, Resmiyati Ansar, Rizki R. Hi. Kama, 2018, Analisis Faktor-Faktor Yang Mempengaruhi Agresivitas Pajak (Studi Empiris Pada Perusahaan Manufaktur Yang Terdaftar Di Bursa Efek Indonesia Periode 2012-2016), Jurnal Penelitian Humano, Vol. 9 No. 2 Edisi November 2018, http://ejournal.unkhair.ac.id/index.php/humano

[20] Suyanto, dan Supramono. 2012. Likuiditas, Leverage, Komisaris Independen dan Manajemen Laba Terhadap Agresivitas Pajak Perusahaan. Jurnal keuangan dan perbankan.

JURNAL ILMIAH KOMPUTERISASI AKUNTANSI Vol. 14, No. 2, Desember $2021: 308-339$ 
Vol.16, No.2, pp.167-177. https://doi.org/10.26905/jkdp.v16i2.1057

[21] Tribunnews. "Indonesia Masuk Peringkat ke-11 Penghindaran Pajak Perusahaan, Jepang No.3, $20 \quad$ November $2017 . \quad$ Diambil dari

http://www.tribunnews.com/internasional/2017/11/20/indonesia-masuk-peringkat-ke-11penghindaran-pajak-perusahaan-jepang-no3 